Florida International University

FIU Digital Commons

$11-15-2019$

\title{
Perception of Travel Motivation and Intention for Chinese Cruise Travelers: Toward an Integrated Model
}

Tianyu Pan

tpan005@fiu.edu

Follow this and additional works at: https://digitalcommons.fiu.edu/etd

Part of the Business Administration, Management, and Operations Commons, Hospitality

Administration and Management Commons, and the Social and Behavioral Sciences Commons

\section{Recommended Citation}

Pan, Tianyu, "Perception of Travel Motivation and Intention for Chinese Cruise Travelers: Toward an Integrated Model" (2019). FIU Electronic Theses and Dissertations. 4307.

https://digitalcommons.fiu.edu/etd/4307

This work is brought to you for free and open access by the University Graduate School at FIU Digital Commons. It has been accepted for inclusion in FIU Electronic Theses and Dissertations by an authorized administrator of FIU Digital Commons. For more information, please contact dcc@fiu.edu. 


\section{FLORIDA INTERNATIONAL UNIVERSITY}

Miami, Florida

\section{PERCEPTION OF TRAVEL MOTIVATION AND INTENTION FOR CHINESE CRUISE TRAVELERS: TOWARD AN INTEGRATED MODEL}

A thesis submitted in partial fulfillment of

the requirements for the degree of MASTER OF SCIENCE

in

HOSPITALITY MANAGEMENT

by

Tianyu Pan

2019 
To: Interim Dean Michael Cheng

School of Hospitality and Tourism Management

This thesis, written by Tianyu Pan, and entitled Perception of Travel Motivation and Intention for Chinese Cruise Travelers: Toward an Integrated Model, having been approved in respect to style and intellectual content, is referred to you for judgment.

We have read this thesis and recommend that it be approved.

Michael Cheng

Miranda Kitterlin-Lynch

Eric Beckman, Co-Major Professor

Jinlin Zhao, Co-Major Professor

Date of Defense: Novermber 15, 2019

The thesis of Tianyu Pan is approved.

Interim Dean Michael Cheng School of Hospitality and Tourism Management

Andrés G. Gil

Vice President for Research and Economic Development and Dean of the University Graduate School

Florida International University, 2019 
(C) Copyright 2019 by Tianyu Pan

All rights reserved. 


\section{DEDICATION}

To those who have inspired me to always reach for my dreams 


\section{ACKNOWLEDGMENTS}

This thesis would not be possible without the guidance and encouragement of Dr. Jinlin Zhao. Your confidence in my abilities helped push me to start and complete this process. If you had not encouraged me to study cruise tourism and to write about something important, this study would never have happened. Also, you brought me to Seatrade Global and Seatrade Asia Pacific, and those fantastic conferences helped me learn more insight into the cruise industry. Thank you for providing encouragement, support, and feedback. You have truly made going through this program worthwhile.

Besides my major professor, I would like to extend my sincere thanks to my thesis committee, Dr. Eric Beckman, Dr. Miranda Kitterlin-Lynch and Interim Dean Michael Cheng. I am grateful for the advice and feedback you provided to me. Your help and support for my thesis cannot be thanked enough. Dr. Eric Beckman as my Co-major professor who spent over 5 hours per week to teach me Structural Equation Modeling (SEM) step by step, and also, he checked and made sure everything going well every single week. Dr. Miranda Kitterlin-Lynch supported me everything in this study, and she is also a mentor in my life, inspiring me with her precious experiences. She made me become a better person in this world. Interim Dean Michael Cheng is an excellent leader in Chaplin School, always providing important suggestions and pointing out correct directions for me. Also, he is the person who suggested me to do thesis track in my Masters' degree, and helped me prepare $\mathrm{PhD}$ application. Thank you for providing so much help to me, and I couldn't imagine how to complete my thesis study if without any of you.

Last but not least, I would like to express my profound gratitude to my parents Chaoxin Pan and Ling Zhang. You have motivated me to continue my education and 
supported me during this roller coaster. You opened my eyes to the world and helped create my love of wanderlust. Thank you for giving me the tools to become the person I am today. 


\title{
ABSTRACT OF THE THESIS \\ PERCEPTION OF TRAVEL MOTIVATION AND INTENTION FOR CHINESE \\ CRUISE TRAVELERS: TOWARD AN INTEGRATED MODEL
}

\author{
by \\ Tianyu Pan
}

Florida International University, 2019

Miami, Florida

Professor Jinlin Zhao, Co-Major Professor

Professor Eric Beckman, Co-Major Professor

Understanding the decision-making process and predicting cruise consumers behavior are critical. This study develops and tests a structural equation model (SEM) using the Theory of Planned Behavior (TPB) and Motivation - Satisfaction Theory to explain Chinese consumers travel motivation and behavioral intention in the cruise industry. Nine hypotheses were proposed regarding the relationships between second-order factor Motivation, travel satisfaction, and the original TPB constructs. Results of the study demonstrated that the integrated model fits the data relatively well, exploring the driving factors of Chinese consumers to participate in cruise travel. The path weight of every hypothesis is significant, and all hypotheses are supported. Chinese consumers' cruise travel motivation highly correlated to cruise travel satisfaction, and travel satisfaction highly positively impact on behavioral intention of cruise traveling in China. Moreover, cruise travel motivation directly affects cruise travel intention in China. This research has both theoretical and managerial implication to the Chinese cruise industry. 


\section{TABLE OF CONTENTS}

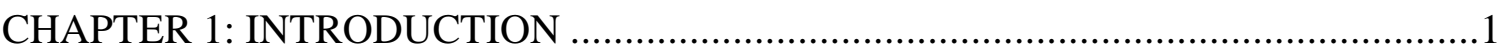

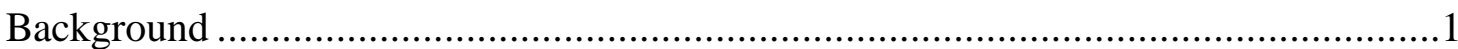

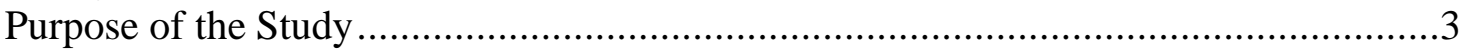

Definition of Terms ....................................................................................4

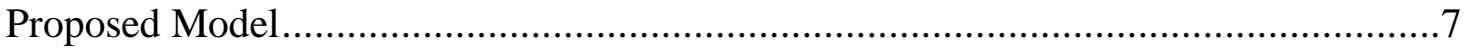

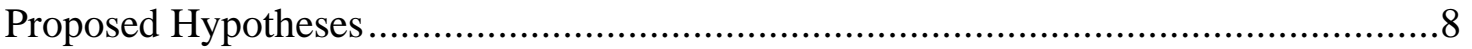

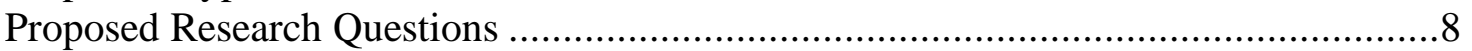

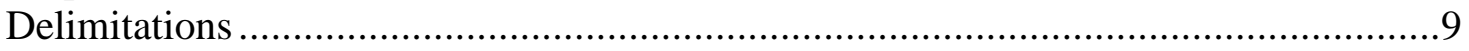

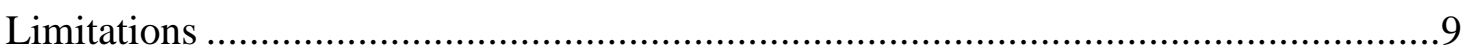

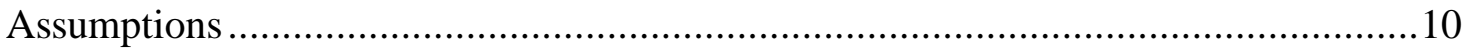

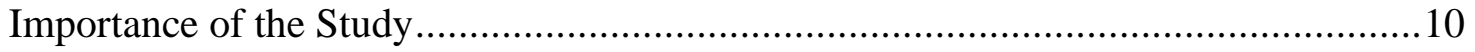

CHAPTER 2: LITERATURE REVIEW ........................................................... 11

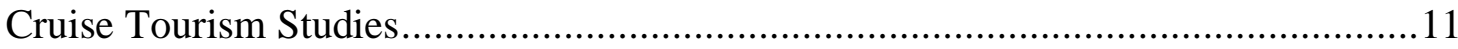

Western and Eastern Traveler Behavior ................................................................. 13

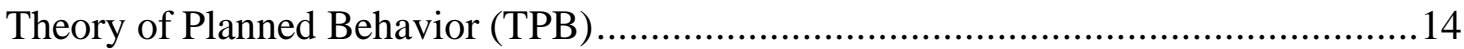

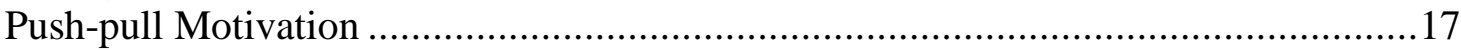

Travel Motivations in the Cruise Industry ........................................................20

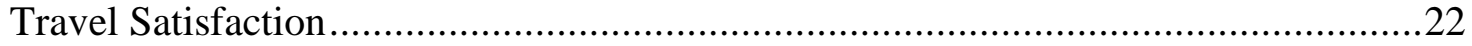

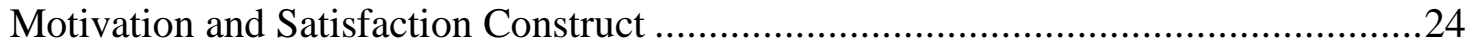

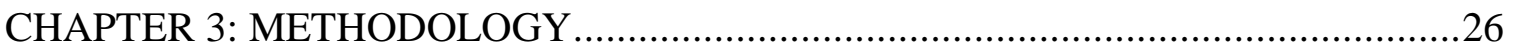

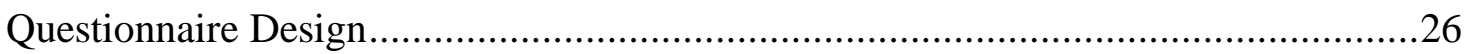

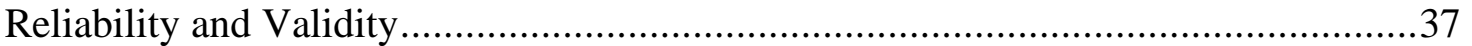

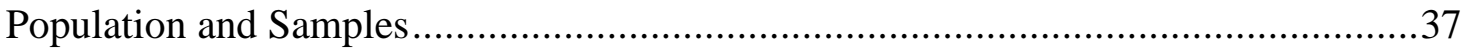

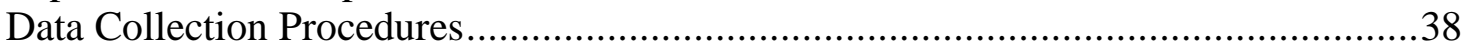

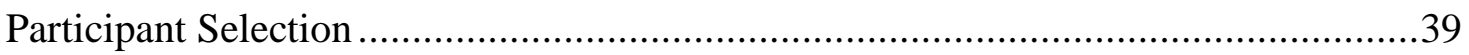

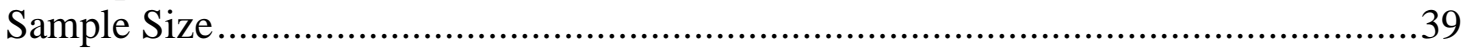

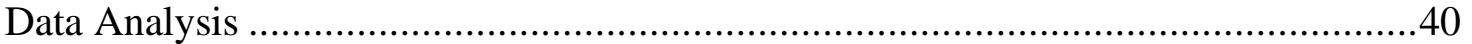

Descriptive Data Collected on Respondents ..........................................................41

Exploratory Factor Analysis (EFA) ................................................................41

Modified Proposed Path Model and hypotheses .............................................51

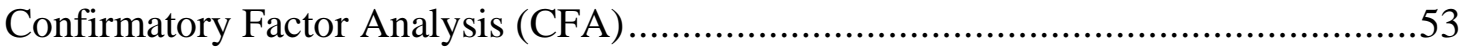

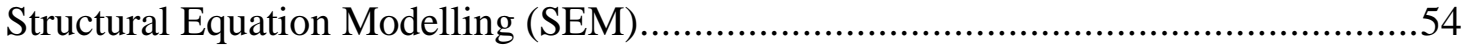

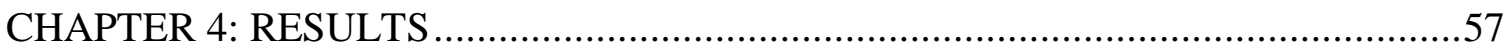

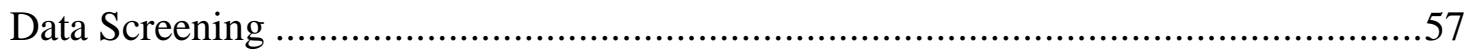

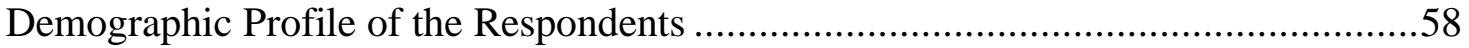

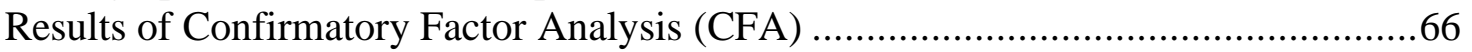

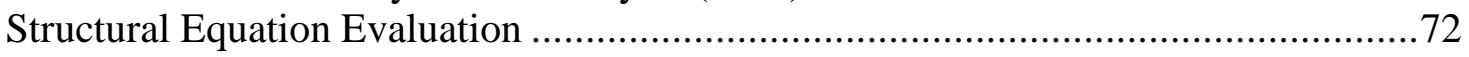

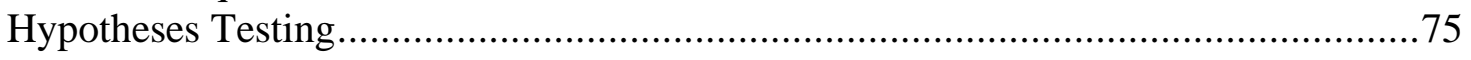

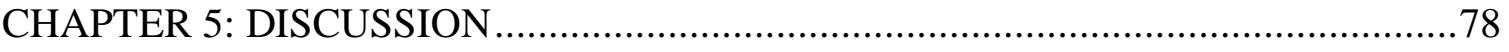

Discussion 1. What do Chinese people prefer when cruising? ...............................78 
Discussion 2. What drives Chinese consumers to participate in cruise travel? ............78

Discussion 3. How might cruise companies attract more consumers in China?..........79

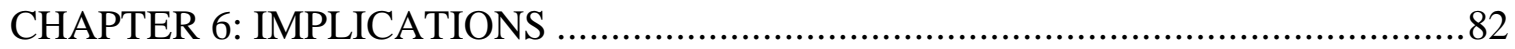

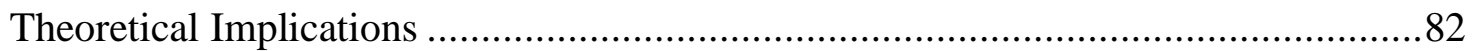

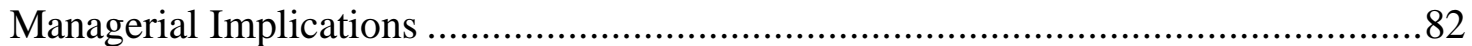

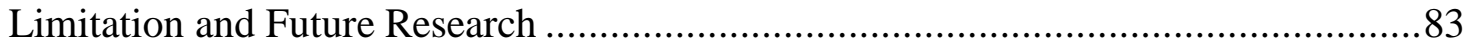

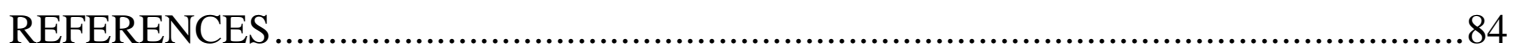

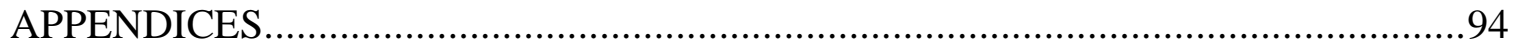




\section{LIST OF TABLES}

TABLE

PAGE

Table 1. Top 10 Cruise Product and Service Delivery for Customers' Satisfaction .23

Table 2. List of Original/Modified Scale Items for Each Construct and Their Source.....28

Table 3. Sample Size

Table 4. Factor loadings based on an exploratory factor analysis with Varimax

(Orthogonal) rotation for 16 items from the Theory of Planned Behavior Scale $(\mathrm{N}=582)$

Table 5. Factor loadings based on an exploratory factor analysis with Varimax

(Orthogonal) rotation for 26 items of the Cruise Traveling Motivational Scale $(\mathrm{N}=582)$

Table 6. Results of the planned behavior EFA factor loadings ................................47

Table 7. Results of the cruise traveling motivation EFA factor loadings.......................49

Table 8. Hypotheses in Modified Proposed Path Model .........................................52

Table 9. Frequently Used Model Fit Indices.....................................................56

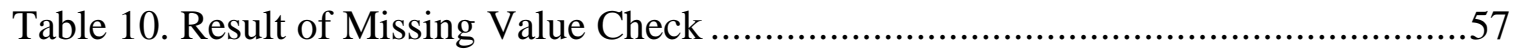

Table 11. Respondents' Demographic Profile............................................................60

Table 12. Cruise Experience (Times) Frequency Analysis .....................................61

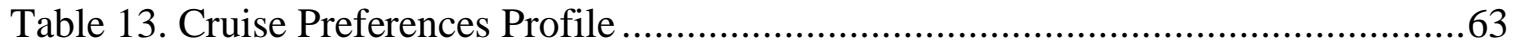

Table 14. Descriptive Statistics of Measurement Items ............................................64

Table 15. Fit Statistics for Each Construct - Refined Model ....................................67

Table 16. Factor Loadings and Composite Reliabilities of the Final Measurement Model

Table 17. Validity and Reliability of the Final Measurement Model............................70

Table 18. Discriminant Validity of the Final Measurement Model ...............................71

Table 19. The Standardized Regression Weights for Hypotheses 1 through $9 \ldots \ldots \ldots \ldots . . . . . . .73$ 


\section{LIST OF FIGURES}

FIGURES

PAGE

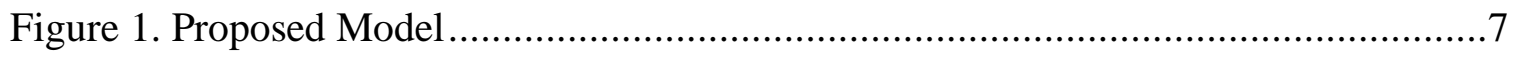

Figure 2. Theory of Planned Behavior (Ajzen, 1991) ......................................... 15

Figure 3.Push-pull Motivation Model (Tsai \& Sakulsinlapakorn, 2016) ........................18

Figure 4. Motivational Driver (Yoon \& Uysal, 2005) ................................................24

Figure 5. Conceptual Model Showing Hypothesized Relationships ............................25

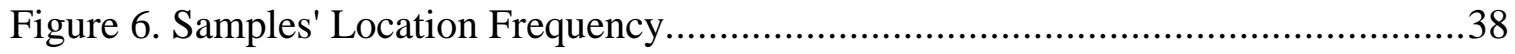

Figure 7. Modified Proposed Path Model..................................................................51

Figure 8. Cruise Experience (Times) Histogram .................................................62

Figure 9. Proposed Research Model with Standardized Regression Weights .................74 


\section{CHAPTER 1: INTRODUCTION}

\section{Background}

The cruise business is one of the most dynamic and fastest-growing segments of the international hospitality and tourism industries (Dwyer \& Forsyth, 1998). Cruise tourism originated in Europe and America. However, within the fast-growing decades in cruise tourism in Europe, America and other developed regions, the regional markets became saturated. Cruise companies began to transfer their focus onto the markets in the Asia Pacific (Zhao, 2018). Globalization has become commonplace as one prominent feature of the new era in cruise tourism (Harvey, 1989). With one-third of the world's population and rapid economic growth, the Asia Pacific area devotes full energy into tourism development and shows the highest demand in cruise tourism (Zhao, 2018).

The number of Asian cruise passengers hit a new high record in 2017, increased by 20.6\%, when compared to that of 2016. Although Mainland China grew slower than in previous years, it maintained its dominance and made up 59\% of all Asian passengers in 2017. The possible reasons for this slowdown could be a mix of regulatory issues, special needs in China's market, and some reductions in ship deployment in East Asia, as the demand for those ships was strong elsewhere in the world (Association Cruise Line International, 2018). Moreover, the cruise industry is not only highly dynamic and globalized but also likely to be affected by regional socio-economic development (Hung \& Petrick, 2010; Park, Hsieh, \& Lee, 2017). As a matter of fact, the Asian market has grown fastest in the world recently and has the most significant potential to develop in the world cruise industry (Association Cruise Line International, 2018). 
The cruise industry seems to be gradually reaching the maturity stage of the life cycle nowadays (Han \& Hyun, 2019), however, Chinese cruise market is still growing and presenting a significant market share within Asia. The cruise industry in China has the potential for continued expansion because China has a long coast with a population of 1.34 billion (Mondou \& Taunay, 2012), and Chinese government encourages development of cruise tourism while maintaining strong regulations (Nyíri, 2008; Yang, 2015). China’s middle- and upper-income classes are growing continuously with the soaring economy and upwardly mobile society (Yang, 2015). Culture is a complex and multi-layered structure, which included many kinds of service-based cultures, such as "cruise culture" and "food culture". Cruise culture has been defined as relaxing and enjoying on-board activities in holidays (Pearce, 2011). Within the development, more and more Chinese travelers are accepting cruise culture in recent years. Moreover, cruise companies have been striving to offer valuable product packages with better prices to retain increasingly demanding travelers and survive in a competitive market (Han \& Hyun, 2019). The difficulty of attracting consumers attentions is increasing under this growingly competitive market environment, so studying Chinese cruise travel intention is more important now than ever in the cruise tourism industry in China (Han \& Hyun, 2019; Hyun \& Han, 2015; S. Kim, Kim, \& Hyun, 2016).

Motivation has been a critical topic in tourism and consumer behavior for a long time, and significantly aroused and guided individuals' behaviors by specific internal variables (Crompton, 1979; Han \& Hyun, 2018). Most scholars have focused on the North American and European cruise markets, but only a few research have investigated the Asian market, especially mainland China, which is the largest potential cruise market in 
the world (Fan, Qiu, Hsu, \& Liu, 2015). Several studies have explored both the Hong Kong and Taiwan cruise markets (Chen, 2016; Josiam, Huang, Spears, Kennon, \& Bahulkar, 2009; Qu \& Ping, 1999), also limited research focused on investigating the emerging cruise market in Mainland China. Fu et al. (2010) examined the motivations of Chinese tourists for cruise tourism by using push-pull motivation construct; Fan et al. (2015) compared motivations and intentions of Chinese potential cruise passengers from different demographic groups; and Fan et al. (2015) explored the preferences of potential Chinese cruisers and their expectations, motivations, and intentions in relation to taking an outbound cruise.

\section{Purpose of the Study}

This study investigated the cruise travel motivation and intention in China by using an integrated model of TPB and Motivation-satisfaction construct. The primary purpose of this research project is to explore what Chinese cruise travelers' want, and how cruise companies satisfy cruise travelers' preferred needs and demands. Although cruise companies developed quickly in the past decade in China, the marketing efficiency and the number of consumers are still lower than other areas. Fundamentally, cruise companies haven't known Chinese cruise travelers' motivation well. In 2018, Norwegian Cruise Line moved its built-for-China ship Norwegian Joy to the United States (Sampson, 2018). The Norwegian Cruise Line annual report showed the profits from Norwegian Joy in China were less than the company expected, and the special cruise distribution method in China (chartered by travel agency) affected the ship's occupancy. Even through the company decorated the cruise ship in Chinese style, the attraction of cruise traveling in China was lower than expected. Compared to the Alaskan market, China's is not as good. 


\section{Definition of Terms}

Consumer perception. The term consumer perception refers to the customers' opinion of a business or product, summarizing how customers feel about a brand including every direct or indirect experience with the company (Stec, 2019). Perception plays an important role in consumers' life, and it is a process of selecting, organizing and interpreting information inputs to create meaningful picture in the world by consumers (Agyekum et al., 2015). When consumers interpret a situation or events, perceptions come out directly and then they can be in position to respond (Kotler, 2000). In this study, the idea of consumer perception referred to cruise traveler's motivation and behavioral intention in China.

Attitude Toward the Behavior (ATT). Compared to the traditional understanding of attitude as a positive or negative evaluation of an object, the attitude toward the behavior in the Theory of Planned Behavior has been defined as a positive or negative evaluation of individual's performance of the behavior in question (Ajzen, 1991, 2009, 2013; Yuzhanin \& Fisher, 2016). In other words, attitude toward the behavior is the likelihood that important referent consumers approve or disapprove of performing a given behavior (Ajzen, 1991).

Subjective norm (SN). Subjective norm has been defined as "individual's perceptions of what others think of a particular behavior" (Ajzen, 1991). An individual's beliefs of what others might think constitute subjective norm; however, those beliefs may not reflect others actual thoughts. Yuzhanin \& Fisher (2016) indicated that "an individual may forego a behavior if there is a belief that the behavior would be unacceptable, or they may decide to act in a way that would not be noticed". 
Perceived behavioral control (PBC). Ajzen (1991) specified that perceived behavioral control indicates an individual's perceptions of their abilities to perform a given behavior, and individual's positive attitudes or intentions would not necessarily lead to action. In some cases, perceived behavioral control could be the sole predictor behavior if the individual's self-control is low. Furthermore, an individual's control beliefs may be based on past experience with the behavior that increase or decrease the perceived difficulty of performing the behavior in question (Ajzen, 1991; Yuzhanin \& Fisher, 2016).

Behavioral intention (INT). Behavioral intention is the central factor in the Theory of Planned Behavior, assuming to capture the motivational factors that influence individual's behaviors. Also, behavioral intention can be seen as how hard people are willing to try or plan to perform the behavior. In general, the stronger the intention to engage in a behavior, the more likely to perform it in the real life (Ajzen, 1991).

Motivation. Crompton \& McKay (1997) defined motivation as "an internal factor that guides or integrates individual's behaviors". Individual motivation has been a crucial topic in the tourism industry in the last few decades (Andriotis \& Agiomirgianakis, 2010; Han \& Hyun, 2019). Furthermore, tourism motivation has been defined as "a dynamic process of internal psychological factors (needs and wants) that generate a state of tension or disequilibrium within individuals" in 1997 (Crompton \& McKay, 1997). This study utilized such motivation dimensions as self-esteem \& social recognition; escape and relaxation; learning, discovery and thrill; socialization and bonding; enjoy nature; and creativity (Hung \& Petrick, 2011; Manfredo, Driver, \& Tarrant, 1996).

Satisfaction. Dunn Ross \& Iso-Ahola (1991) considered satisfaction as "a central concept in understanding tourism behavior". Previous studies suggest that "satisfaction is 
'destination-determined' and formed by experiences, and critically important to investigate cruise passengers' satisfaction levels in various destination attribute (Andriotis \& Agiomirgianakis, 2010; Crompton, 1979; Schneider \& Sönmez, 1999). Consumer satisfaction can be seen as a relationship between the costs of what the consumer spends and the expecting rewards. The major factors in determining consumer satisfaction are price, benefits, time, and effort (Oliver \& Swan, 1989; Yoon \& Uysal, 2005). 


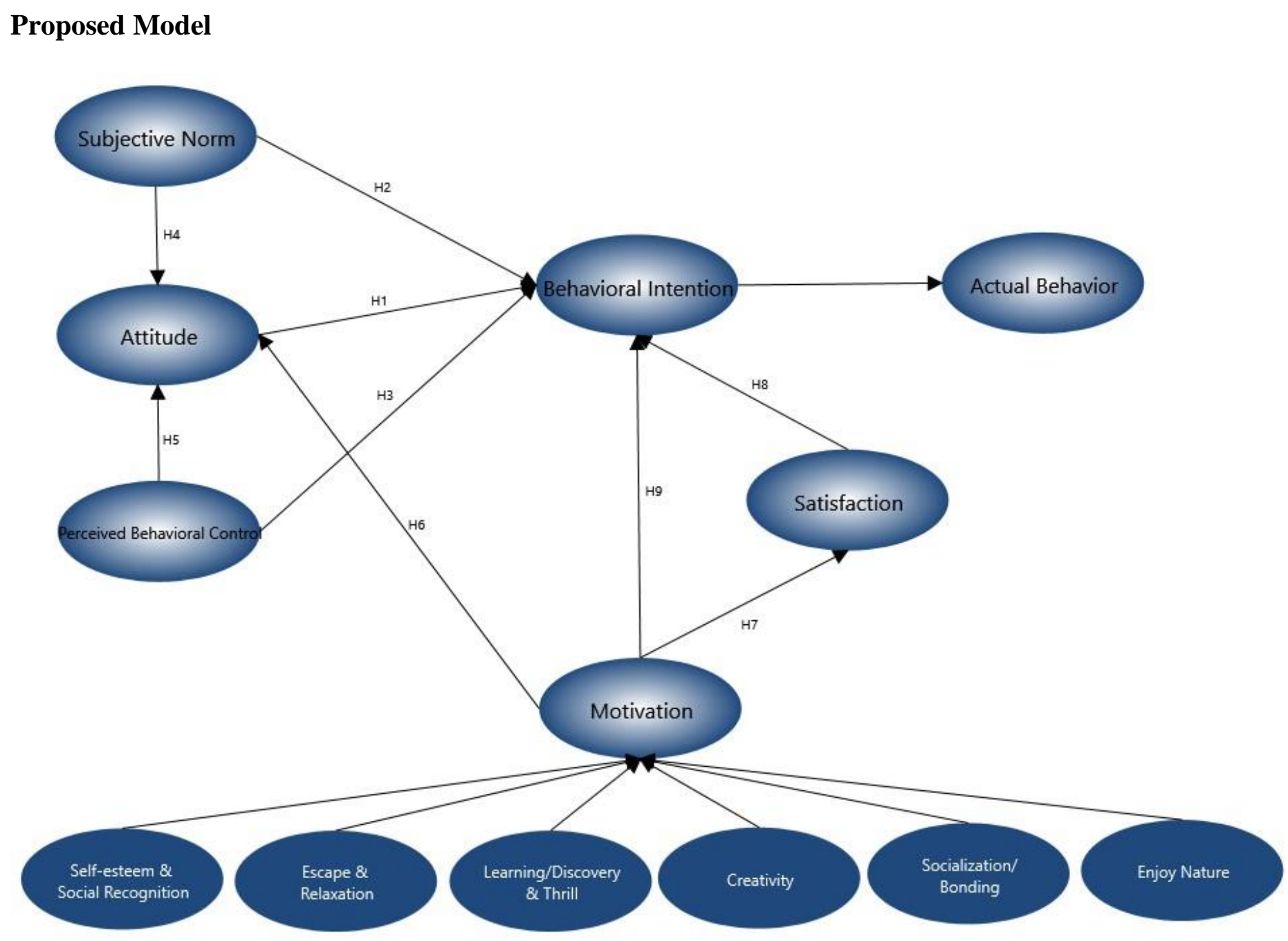

Figure 1. Proposed Model 


\section{Proposed Hypotheses}

H1. Chinese cruise travel attitudes exert a positive influence upon Chinese cruise travel intention.

H2. Subjective norms have a positive effect on Chinese cruise travel intention.

H3. Perceived behavior control positively influences Chinese cruise travel intention.

H4. Subjective norms have a positive effect on Chinese cruise travel attitude.

H5. Perceived behavior control positively influences Chinese cruise travel attitude.

H6. Chinese cruise travel motivation has a positive effect on Chinese cruise travel attitude.

H7. Chinese cruise travel motivation has a positive effect on Chinese cruise travel satisfaction.

H8. Chinese cruise travel satisfaction positively influences Chinese cruise travel intention.

H9. Chinese cruise travel motivation positively directly affects Chinese cruise travel intention.

\section{Proposed Research Questions}

Research Question 1. Do attitudes, subjective norms, and perceived behavior control affect Chinese cruise travel intention?

Research Question 2. Is there a significant relationship among attitudes, subjective norms and perceived behavior control?

Research Question 3. Does Chinese cruise travel motivation affect Chinese cruise traveler's attitudes and satisfaction?

Research Question 4. Does Chinese cruise travel satisfaction influence Chinese cruise travel intention? 
Research Question 5. Does Chinese cruise travel motivation affect Chinese cruise travel behavioral intention?

\section{Delimitations}

This study was delimited by time and location for data collection. Data were collected during a three-week period, starting on September 16, 2019, and ending on September 29, 2019. The data collected for this study focused on consumers who had cruising experience in recent years. The survey was only conducted in Chinese, and Wenjuanxing Survey Platform has been used for the collection of data. Through the database of Wenjuanxing Survey Platform, the survey was sent to Chinese travelers who had cruising experience(s) among 32 provincial-level administrative units, including 23 provinces, 4 municipalities (Beijing, Tianjin, Shanghai, Chongqing), and 5 autonomous regions (Guangxi, Inner Mongolia, Tibet, Ningxia, Xinjiang).

\section{Limitations}

The study was limited by data collection location and sampling. This study was limited to surveys in an online environment. The data collection was restricted to cruise message boards and social media because the researcher could not access nearby cruise ports to survey consumers in person. Even though cruise message boards and social media reach a wide range of individuals, the responses for some age groups were limited. Cruisers 70-years and older may not partake in cruise message boards and social media due to lack of computer access. Data collection was restricted to participants who choose to partake in the survey from cruise message boards and social media. 


\section{Assumptions}

The researcher made the following assumptions: (1) The survey instrument created to question cruise consumers had been designed appropriately to determinate perceptions of travel motivation and intention for Chinese cruise travelers based on the theory models; (2) According to the literature review, the proposed model and hypotheses constructed correctly; (3) All participants in the online survey answered the questions honestly and without any prejudice.

\section{Importance of the Study}

The proposed study is significant for three reasons: first, exploring the motivation and intention of cruise traveling in China; second, integrating important factors that are affecting current cruise traveling market in China by using structural equation modeling (SEM); third, the results of this study could bring a revolution in the Chinese cruise industry and aid cruise companies to attract more consumers in China.

With the fast growth in the cruise industry, limited academic research has been conducted on the topic, especially the cruise travel motivation and intention of Chinese people (Lee \& Ramdeen, 2013; R. E. Wood, 2000). To address this research gap and develop the cruise tourism market in China, this research focused on exploring factors that are affecting Chinese cruise travel motivation and intention and reported how cruise companies will attract more consumers in China. 


\section{CHAPTER 2: LITERATURE REVIEW}

\section{Cruise Tourism Studies}

Cruise tourism has been defined as a luxurious form of traveling. During a minimum 48 hours period, consumers have access to entertainments and accommodations, such as internet, food and beverage, shopping centers, off cruise programs (Research Centre for Coastal Tourism, 2012). Travel motivations in the cruise industry are comprehensive and differ from travelers' motivations for common traveling (Hung \& Petrick, 2011). Due to the limited development, restrictions, and political issues in China, cruising is still a new concept in contemporary China. However, the Chinese market has demonstrated a huge potential and highlighted the role as an essential component of marketing in Asia (Fan et al., 2015). By using qualitative and quantitative methodological approaches, previous studies identified four major categories of cruise travel motivations: “escape/relaxation," "self-esteem and social recognition," "learning/discovery and thrill," and "bonding" (Hung \& Petrick, 2011; Jung \& Han, 2016; Kah \& Lee, 2016; Qu \& Ping, 1999).

Fan et al. (2015) explored the cruise motivation and intention of potential Mainland Chinses cruise passengers firstly, and then verified how the motivation and intention of cruise consumers differed in terms of their demographic background by using qualitative and quantitative methodologies. Different demographic factors could significantly affect cruise motivation and intention, including age, marital status, and income level. However, this study found that gender, family size, and education are insignificant in differentiating cruise motivation and intention. Furthermore, the results showed that factors, such as relaxation, family, and enjoyment, highly positively affect cruising intention in China. 
Mondou \& Taunay (2012) studied the adaptation strategies of the cruise lines to the Chinese tourists by qualitatively analyzing the social, spatial (the cruise tourist practices) and political realities (the political pressure and the strategies of the cruise lines). Furthermore, this study explored the factors that affected Chinese cruise market by applying qualitative semi-structured interviews. The analysis showed that the expectations of Chinese cruise travelers are different from the Americans and Europeans. Especially, most of cruise ships in China focused on Chinese decorations instead of creating spaces for relaxation. Moreover, socializing displayed higher importance than the need to care for oneself.

Hung \& Petrick (2011) explored the motivations for taking cruise holidays, and the construction of a cruising motivation scale by adopting Churchill's (1979) recommended measurement scale and using multi-stage research methodology, including in-depth interviews, experts panel, pilot test, and online panel survey. This study developed a measurement scale for motivations to cruising, including self-esteem and social recognition; escape and relaxation; learning, discovery and thrill; and bonding. Additionally, the researchers examined the influences of cruising motivation on its intention, and a positive relationship was found between these two variables. This indicated that people who have higher cruising motivation are more likely to cruise in the future if cruise lines offered the same conditions.

Han \& Hyun (2019) explored the impact of relationship investment on cruise travel motivations and repeat cruising behavior by using hedonic and utilitarian values, and structural equation modeling. The finding demonstrated the hedonic and utilitarian values are increased by the adequacy of the higher order structure of cruise travel motivations. 
Furthermore, the results verified the comparative importance of overall company image in determining intention, and the mediators between factors.

Fan \& Hsu (2014) investigated the relationship among potential cruise travelers' expectations, motivations, and intentions in Mainland China by using both qualitative and quantitative research methodologies, including focus group interviews, and questionnaire. The analysis showed that most respondents preferred medium length cruises (7-15 days), and 1 to 2 months in advance to begin planning cruise travel. Furthermore, the results proved that "See some beautiful sceneries", "Spend time with friends and family", "Relax", "Have fun", and "Experience different cultures" are the top expectation items; and "Enjoy beautiful environment and sceneries", "Experience attractive routes and destinations", "See and experience new cultures", "Visit different places in one trip", and "Travel to places friends/relatives have not visited" are the top five motivations for potential cruise travelers in China. Moreover, motivation has a positive effect on intention based on the EMI model in this research. This study could be utilized by cruise companies and travel agencies to meet Chinese cruise travelers' needs and maximize the profits from China.

\section{Western and Eastern Traveler Behavior}

The extant has found that cruise travelers' consuming behaviors are different in countries, especially between China and the Western countries. The similarities and differences between Chinese and Western cruise travelers have been explored in prior research (Lyu, Hu, Hung, \& Mao, 2017). The profile of the Chinese cruise market is similar to the Western, which is dominated by leisure travelers with higher education and rich household backgrounds (International, 2013). Additionally, both Chinese and Western cruise travelers have "relaxing" and "escape from normal life" as two common cruise travel 
motivations. However, most of the Western travelers are repeat cruise travelers, but the Chinese are not. This could be because Chinese cruise travelers are usually more sensitive to cruise pricing and have more service requirements on the cruise ship (Sun, Feng, \& Gauri, 2014). Moreover, the behaviors of Chinese cruise travelers, such as connecting with overseas crew members who can speak Chinese more than English, and spending more time in authentic Chinese food than international cuisine, indicated that they have a unique cultural attribute and their activities are more culture-driven (Fan \& Hsu, 2014; International, 2013; Xie, Kerstetter, \& Mattila, 2012). Although understanding different consumer behaviors in countries is significant for marketing management in the cruise industry, only a few studies focused on identifying differences of behavior between Western and Eastern travelers. Hobson \& Josiam (1996) suggested that future research should be conducted on the travel patterns and motivations of sub-cultural and ethnic groups.

\section{Theory of Planned Behavior (TPB)}

Theory of Planned Behavior (TPB) is developed from Theory of Reasoned Action (TRA) and extends TRA by adding perceived behavior control (PBC) as a third independent determinant of behavioral intention (Liu, 2019). The TPB could be simply understood as self-interest and motivational factors affecting people's behaviors and decisions. Based on the theory, the three kinds of principal considerations are behavioral beliefs, normative beliefs, and control beliefs. Behavioral beliefs produce a positive or negative attitude towards behavior (ATT); normative beliefs guide to perceived social pressure or subjective norm (SN); and perceived behavior control (PBC) or self-efficacy is produced by control beliefs (Ajzen, 1991). The three core elements build up connections 
to a behavioral intention (INT). In general, three core elements have positive relationship with behavioral intention, which means if the more favorable the attitude and subjective norm, along with the greater perceived behavioral control, people should have a stronger intention to perform the behavior in question (Ajzen, 2009).

The TPB has been applied to a wide range of examining a variety of social behaviors, especially predicting human behaviors such as alcohol consumption, technology acceptance, physical activity, consumer behavior, and other research (Armitage \& Conner, 2001; Bamberg, Ajzen, \& Schmidt, 2003; Huang, Lin, \& Chuang, 2007). Due to the TPB model having predicted the human behavioral intention with high reliability in prior studies, it is considered as one of the most significant models to understand human action (Chien, Yen, \& Hoang, 2012). Figure 2 presents the TPB model.

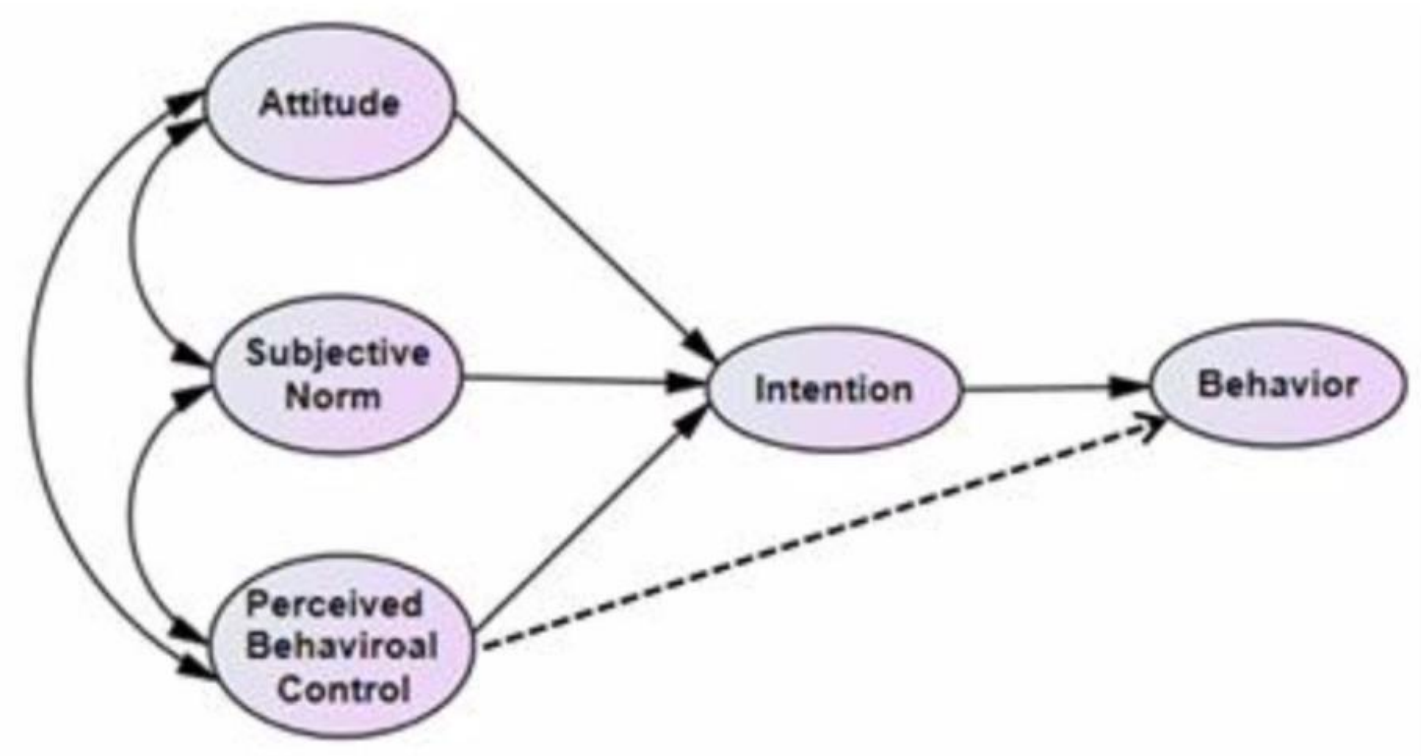

Figure 2. Theory of Planned Behavior (Ajzen, 1991)

Liu (2019) predicted tourists' revisiting behavioral intention in the wind energy tourism context by using an integrative model of the TPB and the Value-Belief-Norm 
Theory (VBN). This study was the first attempt at combining both the TPB and VBN models for explaining and predicting tourists' revisiting behavioral intention in the wind energy tourism context in China. The results have several practical implications, as follows: firstly, marketers could use the results to promote industrial and proenvironmental tourism; secondly, the analysis could help marketers design and implement active initiatives for increasing engagement in industrial and pro-environmental tourism experience; thirdly, government could develop and integrate existing policies for wind energy tourism context by reviewing this study.

Yuzhanin \& Fisher (2016) analyzed the efficacy of the TPB for predicting people's intentions when choosing a travel destination by using 15 studies that applied TPB to predict the choice of travel destination. The TPB in the context of the research has been evaluated, and it showed that measurement scales and precision might vary the efficiency of predicting human's behavior by the TPB in defining the behavior being investigated. Numerous researchers tried to increase the predictive power of the TPB in the tourism context by extending the model or combining related models. Acknowledgment of cultural differences should also be incorporated, especially in considering subjective norms. Moreover, the TPB model is valuable for predicting human behavior when the definitions of behavior are specific, and the strength of the beliefs is incorporated into any study.

Park et al. (2017) examined Chinese college students' intention to travel to Japan and tested destination image and the mediating role of travel constraints by using extended theory of planned behavior and structural equation modeling. The finding showed extended theory of planned behavior is valid and powerful theoretical framework for explaining travel intention and predicting travel behavior. Furthermore, the hypotheses testing proved 
that Chinese students' attitude, social norm, and perceived behavioral control impact their travel intention to Japan directly. Moreover, the results confirmed that the mediating role of travel constraints negatively affect the relationship between travel attitude and intention to Japan, subjective norm and travel intention, and destination image and travel intention.

Hsu \& Huang (2012) investigated relationships among constructs of the model with the addition of motivation and actual behavior in the tourism context by using an extension of the theory of planned behavior. The researchers designed a questionnaire based on the literature review and focus group interviews. A two-wave data collection was implemented with collecting data from 1,524 respondents in Beijing, Shanghai, and Guangzhou in stage 1 and 311 respondents in stage 2 . The results of this study confirmed that the extension of the theory of planned behavior explained 5\% more of the variation in behavioral intention in comparison with a base model without motivation. Also, the study further explored the ability of behavioral intention in predicting actual behavior in a tourism context. The results showed that only a marginal relationship existed between behavioral intention and actual tourist behavior by applying regression analysis. Moreover, the study suggested that researchers needed to do further research to examine the predictive power of behavioral intention on actual behavior.

\section{Push-pull Motivation}

Motivation has been defined as psychological or biological needs and demands that integrate a person's behavior and activity (Dann, 1981; Pearce, 1982; Uysal \& Jurowski, 1994). People may travel to satisfy their physiological (food, climate, and health) and psychological (adventure, relaxation, and family togetherness) needs (Fan \& Hsu, 2014; Mayo, E.J., \& Jarvis, 1981). Prior study indicated that people travel because they are 
pushed and pulled by internal and external forces (Crompton, 1979). Push factors can be explained as motivating people by internal psychological forces, including needs, demands, or emotional factors (Cha, McCleary, \& Uysal, 1995; Crompton, 1979; Kim, 2008). According to the previous studies, push factors could be the need for escape, relaxation, adventure, self-esteem, social recognition, and novelty in the cruise industry (Fan \& Hsu, 2014; Hung \& Petrick, 2011; Josiam et al., 2009). Pull factors are external forces and also explain the attractions and idiosyncrasies of the destination or tourism product itself (Cha et al., 1995; Chul Oh, Uysal, \& Weaver, 1995; Crompton, 1979). Former research showed that pull factors in the cruise industry include national environment and safety; entertainment and sports recreation, nature and wilderness, learning opportunity, and facilities (Fan \& Hsu, 2014; Hung \& Petrick, 2011; Josiam et al., 2009). Figure 3 represent the push-pull motivation model.

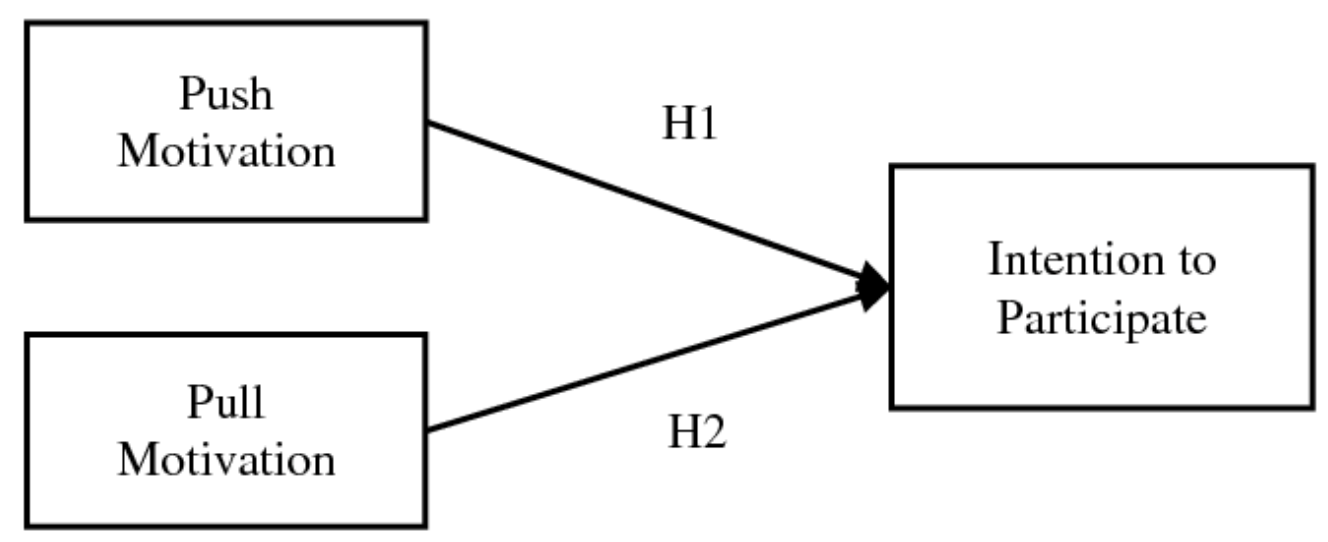

Figure 3.Push-pull Motivation Model (Tsai \& Sakulsinlapakorn, 2016)

According to the literature review, push-pull motivation has been applied to plenty of tourism research to predict travelers' behaviors. Chan, Yuen, Duan, \& Marafa (2018) investigated the push-pull motivations of visitors to the Country Parks in Hong Kong, and 
the socio-demographic characteristics on push-pull motivations have been enhanced. The study selected the push and pull motivation measurement scales from the relevant literature (Cheung, 2013; Figler, Weinstein, Sollers, \& Devan, 1992; Jim, 1989; S. S. Kim, Lee, \& Klenosky, 2003; Mayo, 1975; Mohammad \& Som, 2010), and the data was primarily collected at Shing Mun Country Park and Sai Kung East Country Park in Hong Kong. The results suggested specific market segments to foster local and inbound visits, and this could be applied to tourism and park resources and demands management.

Dean \& Suhartanto (2019) addressed the behavioral intention model in creative tourism by using push and pull motivations, experience quality, perceived value, and visitor satisfaction. This study employed a two-stage model examination using PLS-SEM to review the proposed model and hypotheses. The findings suggested that experience quality, perceived value, satisfaction, and push-pull motivations can be utilized to explain a visitor's behavioral intention after experiencing a creative attraction. Furthermore, the results highlighted the significant role of push motivations on perceived value, and pull motivations have a direct impact on behavioral intention. This implied that pull motivations are not directly affecting experience quality, perceived value, or satisfaction, which is different from previous studies (Devesa, Laguna, \& Palacios, 2010; Wong, Musa, \& Taha, 2017; Yoon \& Uysal, 2005) that have reported a strong influence of pull motivation factors on travelers' satisfaction. Based on the findings, theoretical implications, and managerial implications, the research is valuable and essential to study push-pull motivations.

Tsai \& Sakulsinlapakorn (2016) identified push and pull motivations positively and directly affecting the decision-making of Taiwanese travelers in participating Songkran Festival in Thailand as a cultural destination by using survey technique, Pearson' 
correlation analysis, and simple linear regression. The results showed that Taiwanese highly ranked "To get experience in foreign land," "To relax in foreign land," and "To have enjoyable time with my travel companion(s)" in push motivations; and "Thai food is delicious," "Image of Songkran Festival is wonderful," "In Thailand, people are very friendly and courteous," and "There are many special events in Songkran Festival" in pull motivations. The significant managerial implications were also made for destination marketers, business organizations in the tourism context, and government in Thailand.

However, limited studies have been done in the cruise industry by using push-pull motivation. Fan \& Hsu (2014) explored potential Mainland Chinese cruise travelers' expectations, motivations, and intentions by using push-pull motivation and structural equation modeling. Since this was the first study to apply push-pull motivations in the cruise industry and due to the lack of standardized measurement, a focus group interview was conducted to obtain more insights and explore additional measurement items. For push motivation, the mean values of "Reduce stress," "Escape from routine of work and daily life," and "Accompany family members who want to cruise" are the highest. For pull motivation, potential Chinese cruise travelers highly ranked "Have fun through cruise activities and facilities," "Enjoy luxurious experiences," and "Look for excitement".

\section{Travel Motivations in the Cruise Industry}

In order to comprehend tourism travelers' motivations in the cruise industry, Hung \& Petrick (2011) used a psychometric procedure based on Churchill's (1979) widely accepted paradigm for developing measures (Han \& Hyun, 2018). According to the research of Hung \& Petrick (2011), motivations for cruise traveling are different from common traveling. The study used both qualitative and quantitative research 
methodologies to explore motivation measurement scale of cruise traveling, and it identified four major categories of cruise travel motivations, namely "Self-esteem and social recognition," "Escape and relaxation," "Learning, discovery and thrill," and "Bonding".

Self-esteem and social recognition (SS) are strong motives of traveling with a cruise from vacationers, and it is associated with travelers' self-worthy feeling of consuming a certain tourism product, such as cruise, to impress others (Han \& Hyun, 2018). In this dimension, the perceptions of traveling with cruise eventually are deriving a feeling of accomplishment and increasing the feelings of self-worth. Thus, self-esteem and social recognition have often been categorized into common dimension (Han \& Hyun, 2019).

Escape and relaxation (ER) is the second dimension of cruise travel motivations. Crompton (1979) proved that travelers frequently need a temporary change of environment from daily/routine work and life. Relaxation has been defined as "taking the time to pursue activities of interest, and the activities selected were often a reflection of the increased time available at the vacation destination" (Crompton, 1979; Crompton \& McKay, 1997). Given the definition of relaxation, it as a motive in the cruise industry referred to a mental state rather than a physical relaxation. Generally, vacationers chose cruise travel for escaping from daily/routing life, having fun on cruise, resting their mind, and being free to do whatever they want (Hung \& Petrick, 2011).

Learning, discovery, and thrill is the third category of cruise travel motivation. Travelers in this dimension mostly are seeking for new and unique things, including knowledge, activities, experience, and environments (Han \& Hyun, 2018). The 
measurement items in this cruise travel motivation dimension generally are "To gain knowledge," "To enjoy activities that provides a thrill," and "To experience other cultures".

Bonding is the fourth category of motivation for cruise travel. Crompton (1979) has defined bonding as "going on a pleasure vacation was to meet new people in different locations" in the common tourism context. In the cruise industry, bonding can be seen as a process of facilitation of a close interpersonal relationship on cruise ships (Han \& Hyun, 2019). Bonding represents a strongly interactive and reciprocal process when participating in cruise traveling. Generally, the measurement items in this cruise travel motivation dimension include "Because my friends/family want to cruise," "To interact with friends/family," and "I cruise because I like to meet different people on a cruise ship".

As cruising belongs to leisure traveling, natural scenery and creativity have been considered as motivations in a few cruise research (Duman \& Mattila, 2005; Johnson, 2002; Manfredo et al., 1996; Weeden, Lester, \& Thyne, 2011). The reliable measurement scales for nature scenery and creativity have been applied in previous studies, including "To view the scenic beauty," "To be close to nature," "To enjoy the smells and sounds of nature" in nature scenery; and "To be creative," "To do something creative such as sketch, paint, take photos," "To gain a new perspective on life" in creativity (Crompton, 1979; Manfredo et al., 1996).

\section{Travel Satisfaction}

Satisfaction has been defined as "a comprehensive reaction after consumers experience a product or service" (Josiam et al., 2009). Satisfaction has been examined periodically in the hospitality industry, and the tourism context started considering satisfaction as a key to stay competitive in the industry and attract more consumers (Chang, 
2008). Consumers' needs and demands can easily affect their satisfaction, and every consumer has its own needs and purposes in traveling (Qu \& Ping, 1999). According to Chang (2008) and Qu \& Ping (1999), the satisfaction level of every tourist might be varied. Cruising can be seen as a comprehensive tourism product that integrate all accommodations, restaurants, bars, casino, and leisure activities in one. Teye \& Leclerc (1998) identified that transportation, accommodation, dining, on-board entertainment, recreational activities, domestic and foreign ports of calls, and shore excursions highly attracted North American cruise consumers as main cruise products. Furthermore, the study explored and ranked the top 10 cruise product and service delivery areas that are important measures of satisfaction for North American cruise customers. Table 1 presented the top 10 cruise product and service delivery for customers' satisfaction.

Table 1. Top 10 Cruise Product and Service Delivery for Customers' Satisfaction

\begin{tabular}{ll}
\hline Rank & Top 10 Cruise Product and Service Delivery for Customers' Satisfaction \\
\hline 1 & Cabin service \\
2 & Dining room service \\
3 & Cleanliness of ship \\
4 & Cruise staff \\
5 & Entertainment \\
6 & Bar service \\
7 & Ports of call \\
8 & Quality of food \\
9 & Purser staff/info desk \\
10 & Shore tours \\
\hline
\end{tabular}

Note. From "Product and Service Delivery Satisfaction Among North American Cruise Passengers," by V. Teye and D. Leclerc, 1998, Tourism Management, 19(2), 153-160.

Since cruise tourism has only developed for the past 10 years in Mainland China, there's a lack of literature review focused on cruise tourists' satisfaction. Therefore, for the 
purpose of the current study, the researcher invited consumers who had cruise travel experience(s) to measure satisfaction by 7-Likert-Point scale.

\section{Motivation and Satisfaction Construct}

According to Yoon \& Uysal (2005), tourist travel is mainly driven by push factors and pull factors. This study has proved that push and pull motivators directly impact on tourist satisfaction; however, due to every consumer has its own needs and purposes in traveling, tourists may have different motivations, satisfaction levels, and standards for participating in cruise traveling. Figure 4 represent the relationship between motivations and satisfaction.

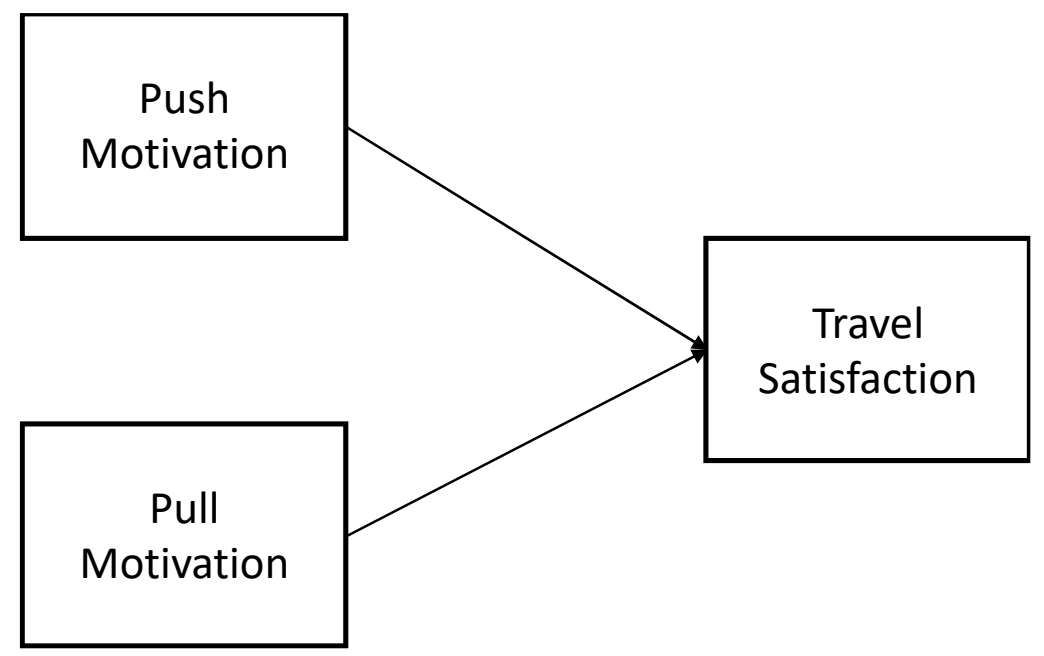

Figure 4. Motivational Driver (Yoon \& Uysal, 2005)

Yoon \& Uysal (2005) examined the effects of motivation and satisfaction on destination loyalty in Northern Cyprus, which located on the Mediterranean Sea. This study provided a comprehensive approach to understand tourist motivations and extended the theoretical and empirical evidence on the causal relationships among the push-pull motivations, satisfaction, and destination loyalty. The data analysis proved that hypothetical model is supported, and the findings provided theoretical implications to 
future studies. Moreover, managerial implications of this research project suggested that it is worthy for destination managers to make greater investments in their tourism destination resources if they are planning to enhance consumers' experiences.

Agyeiwaah, Otoo, Suntikul, \& Huang (2019) explored the relationships between motivation, experience, satisfactions, and loyalty in a culinary tourist context by using structural equation modeling. Researchers focused on the antecedents and outcomes of culinary tourist participation in cooking classes. The results showed that culinary tourists' motivations have positive effects on both the culinary experience and satisfactions, and the more tourists are motivated to participate in cooking classes, the more experiential value and satisfaction are perceived. In addition, this research firstly combined motivation factors in the culinary tourist context with satisfaction construct, and the data analysis proved that hypothetical model is supported. Figure 5 represent theoretical framework in Agyeiwaah et al. (2019).

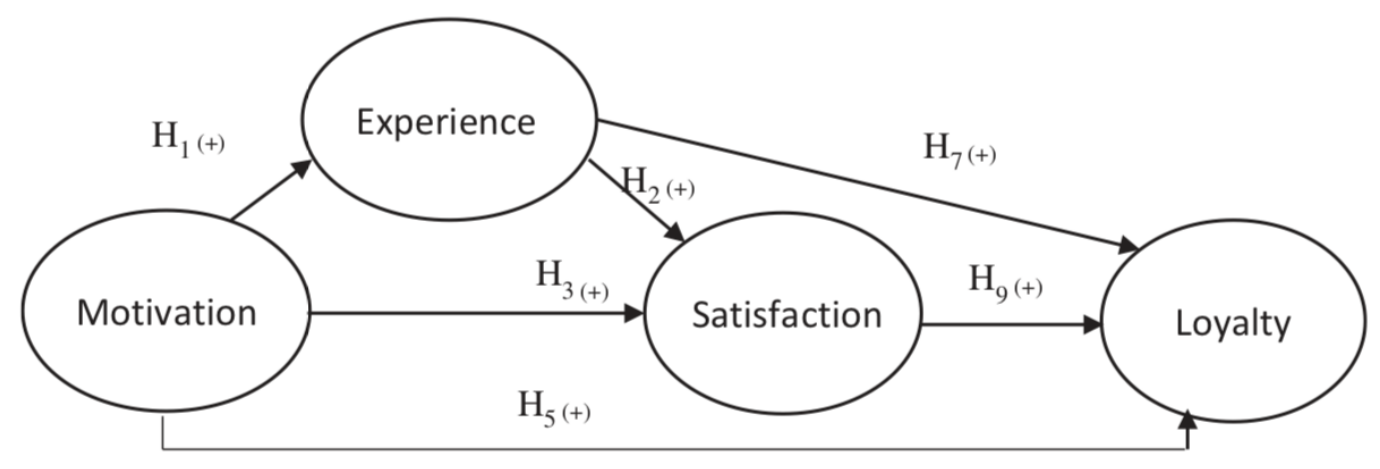

Figure 5. Conceptual Model Showing Hypothesized Relationships

Based on the literature review above, for the purpose of the current study, travel motivations in the cruise industry has been combined with satisfaction construct to explore the relationships in the Mainland China market. 


\section{CHAPTER 3: METHODOLOGY}

\section{Questionnaire Design}

A quantitative approach with survey technique was applied to this study. Survey is a popular way for measuring attitudes and orientations in a large population and it was used most frequently in the past studies with the TPB model (Ajzen, 1991, 2009, 2013; Chien et al., 2012; Lam \& Hsu, 2006). The questionnaire was constructed by following Ajzen's (1991, 2013) comments, and combined with minor changes based on Fan \& Hsu (2014); Hsu \& Huang (2012) and Liu (2019). According to the measurement scales in Han \& Hyun (2019); Hung \& Petrick (2011) and Manfredo et al. (1996), six motivation factors were constructed in this study, including Self-esteem and social recognition; Escape and relaxation; Learning, discovery and thrill; Socialization and bonding; Nature scenery; and Creativity. For content reliability and validity, the measurement items were developed based on literature reviews, and the pilot study was conducted in mainland China with 39 respondents. Five scholars were invited to check if these items were suitable to evaluate Chinese cruise travel intention. The survey instrument was designed in English and translated into Chinese by using a blind translation-back-translation methodology (Brislin, 1976), which was reviewed by several cruise related Chinese professors in Shanghai, one Chinese professor and one research assistant in hospitality school within the United States to ensure accuracy of translation. Through these procedures, a few corrections and adjustments were made in the wording, measurement items, and structure of the questionnaire.

The questionnaire devised consisted of four parts. The first part focused on four sets of questions on attitude towards behavior (6 items), subjective norm (5 items), 
perceived behavioral control (5 items), and behavioral intention (5 items), respectively, using a 7-point Likert scale ranging from $1=$ Strongly disagree to $7=$ Strongly agree. The second part structured six sets of questions on self-esteem and social recognition (5 items), escape and relaxation (5 items), learning/discovery and thrill (4 items), socialization and bonding ( 5 items), nature scenery ( 4 items), and creativity ( 3 items). The third part focused on consumers travel satisfaction after participating in cruise traveling, consisting with 4 questions. The fourth part concerned respondent cruise preferences (4 questions) and demographics (7 questions) such as preferred cruise destination(s), preferred booking channel, preferred cruise duration, gender, age, annual income, and so forth. Table 2 presented the list of original and modified scale items for each construct and their sources. 
Table 2. List of Original/Modified Scale Items for Each Construct and Their Source

\begin{tabular}{|c|c|c|c|}
\hline Factor & Original Scale Items & Modified Scale Items & Source \\
\hline TPB: Attitude & $\begin{array}{l}\text { For me, traveling in Japan is good. } \\
\text { For me, traveling in Japan is valuable. } \\
\text { For me, traveling in Japan is pleasant. } \\
\text { For me, traveling in Japan is beneficial. } \\
\text { For me, traveling in Japan is } \\
\text { interesting. } \\
\text { I think visiting the wind farm is fun. } \\
\text { I think visiting the wind farm is } \\
\text { enjoyable. } \\
\text { I think visiting the wind farm is } \\
\text { pleasant. } \\
\text { I think visiting the wind farm is } \\
\text { favorable. }\end{array}$ & $\begin{array}{l}\text { For me, cruising is pleasant. } \\
\text { For me, cruising is fun. } \\
\text { For me, cruising is enjoyable. } \\
\text { For me, cruising is valuable. } \\
\text { For me, cruising is interesting. } \\
\text { For me, cruising is safe. }\end{array}$ & $\begin{array}{l}\text { (Park et al., } \\
\text { 2017) } \\
(\text { Liu, 2019) }\end{array}$ \\
\hline
\end{tabular}




\begin{tabular}{|c|c|c|c|}
\hline $\begin{array}{l}\text { TPB: Subjective } \\
\text { Norm }\end{array}$ & $\begin{array}{l}\text { I will travel to Japan because it is } \\
\text { popular among my friends/family. } \\
\text { I will travel to Japan because my } \\
\text { friends/family have talked a lot about it. } \\
\text { I will travel to Japan because it has } \\
\text { been recommended by friends/family. } \\
\text { I would like to visit wind farms because } \\
\text { I have heard a lot about wind farms } \\
\text { from my family \& friends. } \\
\text { My family \& friends think it would be } \\
\text { good to visit wind farms. } \\
\text { I would like to visit the wind farms } \\
\text { because my family \& friends visited the } \\
\text { wind farms. }\end{array}$ & $\begin{array}{l}\text { I will participate in cruise travel } \\
\text { because it is popular among my } \\
\text { friends/family. } \\
\text { I will participate in cruise travel } \\
\text { because my friends/family have } \\
\text { talked a lot about it. } \\
\text { I will participate in cruise travel } \\
\text { because it has been recommended by } \\
\text { friends/family. } \\
\text { I will participate in cruise travel } \\
\text { because my friends/family } \\
\text { participated. } \\
\text { I will participate in cruise travel } \\
\text { because my friends/family think it is } \\
\text { good to participate. }\end{array}$ & $\begin{array}{l}\text { (Park et al., } \\
\text { 2017) } \\
\text { (Liu, 2019) }\end{array}$ \\
\hline
\end{tabular}




\begin{tabular}{|c|c|c|c|}
\hline & $\begin{array}{l}\text { My family \& friends have } \\
\text { recommended me to visit the wind } \\
\text { farms. }\end{array}$ & & \\
\hline $\begin{array}{l}\text { TPB: Perceived } \\
\text { Behavioral Control }\end{array}$ & $\begin{array}{l}\text { I feel nothing will prevent me from } \\
\text { traveling to Japan if I want. } \\
\text { I have enough money to travel to Japan. } \\
\text { I have enough time to travel to Japan. } \\
\text { I am confident that if I want, I can } \\
\text { participate in wind energy tourism. } \\
\text { I have enough time and energy to } \\
\text { participate in wind energy tourism. } \\
\text { For me to participate in wind energy } \\
\text { tourism is not a difficult thing. } \\
\text { I have plenty of opportunities to } \\
\text { participate in wind energy tourism. }\end{array}$ & $\begin{array}{l}\text { I have enough time to participate in } \\
\text { cruise travel. } \\
\text { I have enough money to participate in } \\
\text { cruise travel. } \\
\text { I have enough opportunities to } \\
\text { participate in cruise travel. } \\
\text { I feel nothing will prevent me from } \\
\text { participating in cruise travel if I want. } \\
\text { If I want, I can easily participate in } \\
\text { cruise travel. }\end{array}$ & $\begin{array}{l}\text { (Park et al., } \\
\text { 2017) } \\
\text { (Liu, 2019) }\end{array}$ \\
\hline
\end{tabular}




\begin{tabular}{|c|c|c|c|}
\hline $\begin{array}{l}\text { Motivation: Self- } \\
\text { esteem \& Social } \\
\text { Recognition }\end{array}$ & $\begin{array}{l}\text { To do something that impresses others. } \\
\text { To help me feel like a better person. } \\
\text { To increase my feelings of self-worth. } \\
\text { To derive a feeling of accomplishment. } \\
\text { To photograph an exotic place to show } \\
\text { friends. } \\
\text { I cruise to do something that impresses } \\
\text { others. } \\
\text { I cruise to help me feel like a better } \\
\text { person. } \\
\text { I cruise to increase my feelings of self- } \\
\text { worth. } \\
\text { I cruise to photograph an exotic place } \\
\text { to show friends. }\end{array}$ & $\begin{array}{l}\text { To do something that impresses } \\
\text { others. } \\
\text { To help me feel like a better person. } \\
\text { To increase my feelings of self- } \\
\text { worth. } \\
\text { To derive a feeling of } \\
\text { accomplishment. } \\
\text { To photograph an exotic place to } \\
\text { show friends. }\end{array}$ & $\begin{array}{l}\text { (Hung \& Petrick, } \\
2011) \\
\text { (Han \& Hyun, } \\
\text { 2019) }\end{array}$ \\
\hline $\begin{array}{l}\text { Motivation: Escape \& } \\
\text { Relaxation }\end{array}$ & $\begin{array}{l}\text { So that I can be free to do whatever I } \\
\text { want. }\end{array}$ & $\begin{array}{l}\text { So that I can be free to do whatever I } \\
\text { want. }\end{array}$ & $\begin{array}{l}\text { (Hung \& Petrick, } \\
\text { 2011) }\end{array}$ \\
\hline
\end{tabular}




\begin{tabular}{|c|c|c|c|}
\hline & $\begin{array}{l}\text { To escape. } \\
\text { To give my mind a rest. } \\
\text { I cruise so that I can be free to do } \\
\text { whatever I want. } \\
\text { I cruise to give my mind a rest. } \\
\text { To have more privacy than you have } \\
\text { back home. } \\
\text { To get away from the usual demands of } \\
\text { life. }\end{array}$ & $\begin{array}{l}\text { To give my mind a rest. } \\
\text { I cruise to have fun. } \\
\text { To have more privacy than you have } \\
\text { back home. } \\
\text { To get away from the usual demands } \\
\text { of life. }\end{array}$ & $\begin{array}{l}\text { (Han \& Hyun, } \\
\text { 2019) } \\
\text { (Manfredo et al., } \\
\text { 1996) }\end{array}$ \\
\hline $\begin{array}{l}\text { Motivation: } \\
\text { Learning/Discovery } \\
\text { \& Thrill }\end{array}$ & $\begin{array}{l}\text { To gain knowledge. } \\
\text { To enjoy activities that provides a thrill. } \\
\text { To experience other cultures. } \\
\text { I cruise to gain new or different } \\
\text { knowledge. } \\
\text { I cruise to enjoy activities that provide } \\
\text { a thrill. }\end{array}$ & $\begin{array}{l}\text { To gain knowledge. } \\
\text { To experience other cultures. } \\
\text { To discover something new. } \\
\text { To learn more about nature. }\end{array}$ & $\begin{array}{l}\text { (Hung \& Petrick, } \\
\text { 2011) } \\
\text { (Han \& Hyun, } \\
\text { 2019) }\end{array}$ \\
\hline
\end{tabular}




\begin{tabular}{|c|c|c|c|}
\hline & $\begin{array}{l}\text { I cruise to experience other cultures. } \\
\text { I cruise to do something new and } \\
\text { different. }\end{array}$ & & \\
\hline $\begin{array}{l}\text { Motivation: } \\
\text { Socialization/Bonding }\end{array}$ & $\begin{array}{l}\text { Because my friends/family want to } \\
\text { cruise. } \\
\text { To interact with friends/family. } \\
\text { I cruise because my friends/family want } \\
\text { to cruise. } \\
\text { I cruise to interact with friends/family. } \\
\text { To be with others who enjoy the same } \\
\text { things you do. } \\
\text { To be with people having similar } \\
\text { values. } \\
\text { To talk to new and varied people. }\end{array}$ & $\begin{array}{l}\text { Because my friends/family want to } \\
\text { cruise. } \\
\text { To interact with friends/family. } \\
\text { Cruising provides me a chance to } \\
\text { meet new people. } \\
\text { I cruise because I like to meet } \\
\text { different people on a cruise ship. } \\
\text { To be with other who enjoy the same } \\
\text { things you do. }\end{array}$ & $\begin{array}{l}\text { (Hung \& Petrick, } \\
\text { 2011) } \\
\text { (Han \& Hyun, } \\
\text { 2019) } \\
\text { (Manfredo et al., } \\
\text { 1996) }\end{array}$ \\
\hline $\begin{array}{l}\text { Motivation: Nature } \\
\text { Scenery }\end{array}$ & $\begin{array}{l}\text { To view the scenery. } \\
\text { To view the scenic beauty. }\end{array}$ & $\begin{array}{l}\text { To view the scenic beauty. } \\
\text { To be close to nature (e.g. Ocean). }\end{array}$ & $\begin{array}{l}\text { (Manfredo et al., } \\
\text { 1996) }\end{array}$ \\
\hline
\end{tabular}




\begin{tabular}{|c|c|c|c|}
\hline & $\begin{array}{l}\text { To be close to nature. } \\
\text { To enjoy the smells and sounds of } \\
\text { nature. } \\
\text { To be where things are natural. }\end{array}$ & $\begin{array}{l}\text { To enjoy the smells and sounds of } \\
\text { nature. } \\
\text { To be where things are natural. }\end{array}$ & \\
\hline $\begin{array}{l}\text { Motivation: } \\
\text { Creativity }\end{array}$ & $\begin{array}{l}\text { To be creative. } \\
\text { To do something creative such as } \\
\text { sketch, paint, take photos. } \\
\text { To gain a new perspective on life. }\end{array}$ & $\begin{array}{l}\text { To be creative. } \\
\text { To do something creative such as } \\
\text { diving, game changers, marquee } \\
\text { shows. } \\
\text { To gain a new perspective on life. }\end{array}$ & $\begin{array}{l}\text { (Manfredo et al., } \\
\text { 1996) }\end{array}$ \\
\hline Travel Satisfaction & $\begin{array}{l}\text { How does Northern Cyprus, in general, } \\
\text { rate compared to what you expected? } \\
\text { Was this visit worth your time and } \\
\text { effort? } \\
\text { Overall, how satisfied were you with } \\
\text { your holiday in Northern Cyprus? }\end{array}$ & $\begin{array}{l}\text { Overall, I am satisfied with my } \\
\text { experience with cruise traveling. } \\
\text { Overall, cruise traveling worth my } \\
\text { time and effort. } \\
\text { Overall, cruise traveling is much } \\
\text { better than what I expected. }\end{array}$ & $\begin{array}{l}\text { (Yoon \& Uysal, } \\
\text { 2005) }\end{array}$ \\
\hline
\end{tabular}




\begin{tabular}{|c|c|c|c|}
\hline & $\begin{array}{l}\text { How would you rate Northern Cyprus } \\
\text { as a vacation destination compared to } \\
\text { other similar places (islands/countries) } \\
\text { that you may have visited? }\end{array}$ & $\begin{array}{l}\text { Overall, cruise traveling as a vacation } \\
\text { option is much better than similar } \\
\text { options (flight, train, etc.). }\end{array}$ & \\
\hline Behavioral Intention & $\begin{array}{l}\text { I will save time and money within } 24 \\
\text { months for the purpose of traveling in } \\
\text { Japan. } \\
\text { I will travel to Japan with } \\
\text { friends/family within } 24 \text { months. } \\
\text { Japan is my first choice for traveling } \\
\text { overseas in the future. } \\
\text { I'll recommend a cruise to others. } \\
\text { I want to cruise sometime in the future. } \\
\text { I intend to cruise in the next three } \\
\text { years. } \\
\text { I am interested in cruise travel. }\end{array}$ & $\begin{array}{l}\text { I'll encourage friends/family to } \\
\text { participate in cruise travel. } \\
\text { I want to participate in cruise travel } \\
\text { within } 12 \text { months. } \\
\text { I intend to cruise on special day in the } \\
\text { future (e.g. birthday, anniversary, } \\
\text { etc.). } \\
\text { Cruise traveling is my first choice for } \\
\text { traveling in the future. } \\
\text { I will save time and money within } 12 \\
\text { months for participating in cruise } \\
\text { travel. }\end{array}$ & $\begin{array}{l}\text { (Park et al., } \\
\text { 2017) } \\
\text { (Fan \& Hsu, } \\
\text { 2014) }\end{array}$ \\
\hline
\end{tabular}




\begin{tabular}{|l|l|l|l|}
\hline & $\begin{array}{l}\text { I'll encourage friends and relatives to } \\
\text { go on a cruise. }\end{array}$ & & \\
\hline
\end{tabular}




\section{Reliability and Validity}

Previous studies showed that Cronbach's alpha is an important index to examine the reliability of the questionnaire (Chen, 2016; Liu, 2019). The purposes of the pilot test in this study were to assess the content validity of the measurement items and the internal consistency of each instrument used in this study; and to make sure the questionnaire has been worded in a proper way and gather information to evaluate the respondents' understanding of the meaning of questions.

For the content reliability and validity, the measurement items were developed based on literature reviews, and a convenient survey was conducted to 39 people who had cruise experience(s) in China through Wenjuanxing Survey Platform in June 2019. Five scholars were invited to check if these items were suitable to evaluate Chinese cruise travel intention, motivation and satisfaction, especially to check the appropriateness of the English to Chinese translation. Based on scholars' comments and the results of pilot test, measurement items were finalized to collect data after minor revisions.

\section{Population and Samples}

The purpose of the study was to have a better understanding on cruise travelers' motivation, behavioral intention and satisfaction in Mainland China. The population selected to represent cruise traveling in China were travelers who had at least one cruise travel experience in Mainland China in the recent five years (from 2014 to 2019). All the surveys were collected during a three-week period, which started on September 16, 2019, and ended on October 4, 2019. The researcher distributed the samples by using Wenjuanxing Survey Platform Sample Services. Wenjuanxing Survey Platform filtered samples based on the requirements of research, and the researcher double-checked and 
deleted meaningless data, leading to reliable factors and ultimately positive outcomes relating to the research objectives. The sample included 582 Chinese cruise travelers representative of the total Chinese cruise travelers that cruised in the last five years. Most of the respondents are from East China, primarily living in Shanghai, Jiangsu, Zhejiang, Anhui, Fujian, Jiangxi and Shandong provinces. Figure 6 presented samples' location statistic within this study.

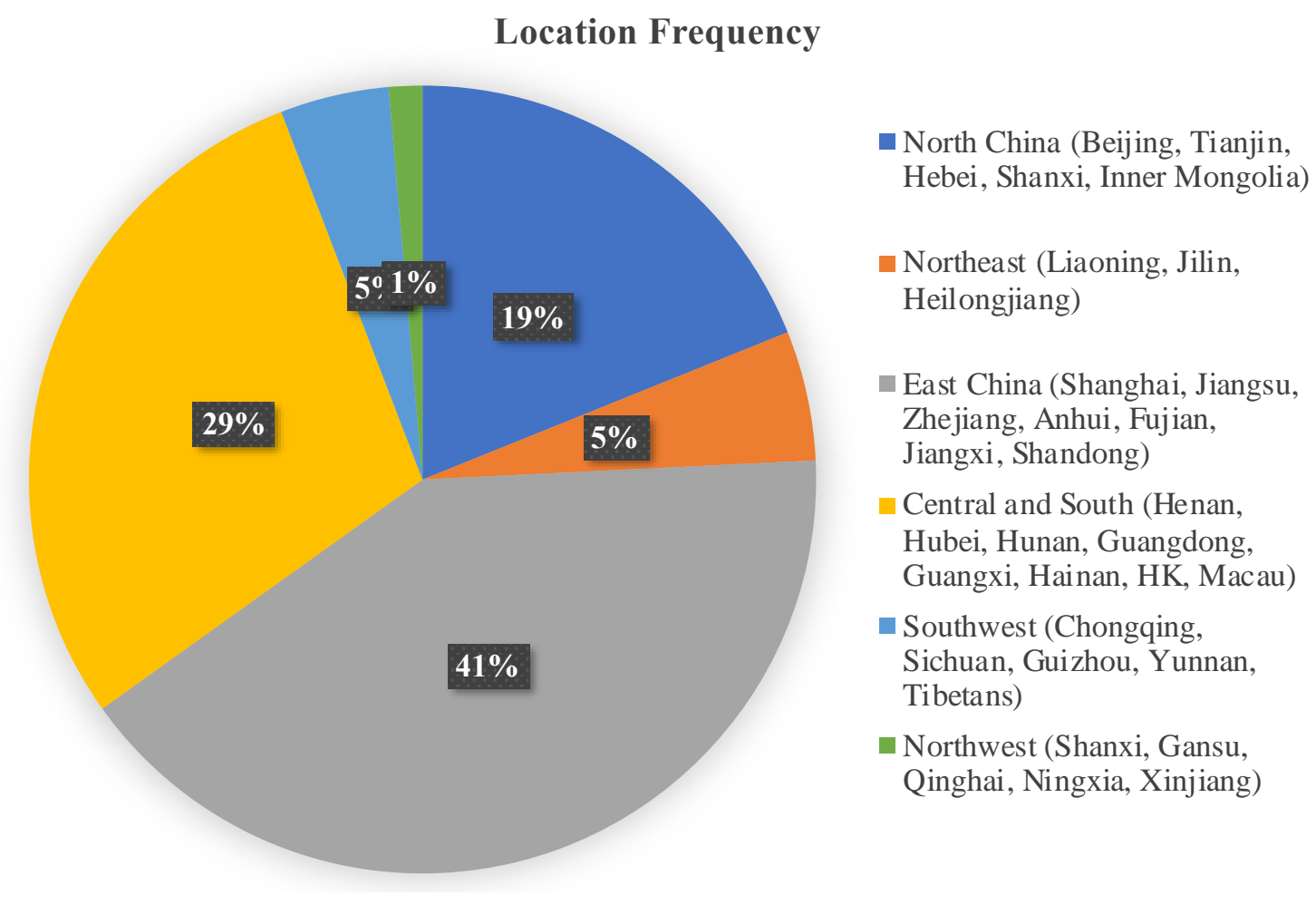

Figure 6. Samples' Location Frequency

\section{Data Collection Procedures}

Six hundred questionnaires were distributed in Mainland China through Wenjuanxing Survey Platform and 582 completed questionnaires were collected, resulting in a response rate of 97 percent. This study used Sample Services in Wenjuanxing Survey Platform, and the researcher set up strict requirements and question's logics. Wenjuanxing 
Survey Platform filtered responses based on these requirements, increasing the reliability and validity of results. According to the question's logics in this survey, respondents were not be able to skip any questions. The logics within the survey helped to reduce missing values.

\section{Participant Selection}

Survey participants were adults aged 21 and older, who are Chinese resident and had participated in cruise traveling at least once in the past five years. The researcher briefly explained the purpose of this study and cruise traveling concept at the beginning of the survey and thanked them for their time and effort in completing the survey at the end. This study and survey have been approved by Institutional Review Board (IRB), which outlined the confidentiality and anonymity of the answers provided by the cruise travelers in China. After the survey was completed by respondents and collected by Wenjuanxing Survey Platform, the researcher checked completed surveys to be sure that no page was skipped and organized surveys' data on the laptop. This process helped to reduce missing values and kept the data in a clean format.

\section{Sample Size}

Sample size is important to structural equation modeling (SEM) study, and a researcher should consider that an increased sample size produces greater power for statistic tests (Creswell, 2012). The literature suggested that the sample size for a structural equation modeling study is 200 or greater, in particular, 10 to 15 observations of one variables could get better results in SEM study (Reisinger \& Mavondo, 2006; Reisinger \& Turner, 1999; Schumm \& Stevens, 1993). Any study especially when a large number of variables are measured, 350 or more participants are suggested (Creswell, 2012). 
According to the statement above, this study needs to survey at least 510 cruise travelers, and 582 respondents completed the survey in Mainland China.

Table 3. Sample Size

\begin{tabular}{lrl}
\hline \multicolumn{1}{c}{ Variables } & \# of items & Sample Size Estimated \\
\hline Attitude & 6 & \\
Subjective Norm & 5 & \\
Perceived Behavioral Control & 5 & $51 \times 10=510$ Minimum \\
Self-esteem \& Social & 5 & \\
Recognition & 5 & \\
Escape \& Relaxation & 4 & $51 \times 15=765$ Taget \\
Learning/Discovery \& Thrill & 5 & \\
Socialization/Bonding & 4 & \\
Nature Scenery & 3 & $51 \times 20=1,020$ \\
Creativity & \multicolumn{1}{c}{ Desirable } \\
Travel Satisfaction & 4 & \\
Behavioral Intention & 5 & \\
TOTAL \# OF ITEMS & $\mathbf{5 1}$ & \\
\hline
\end{tabular}

\section{Data Analysis}

Statistical Packages for Social Science (SPSS) and AMOS version 23 were used to analyze the data collected. Data was analyzed using descriptive statistics to provide cruise preferences and demographics profile of the respondents. Exploratory factor analysis (EFA) was applied to reduce the measurement items of attitude towards behavior, subjective norm, perceived behavioral control, and behavioral intention. Confirmatory factor analysis (CFA) was used to test the model fit and finally the model and hypotheses were tested by using AMOS to do structural equation modelling. 


\section{Descriptive Data Collected on Respondents}

Descriptive statistics were used to determine the mean value and standard deviation scores for the survey constructs. Researchers analyzed the consumer preferences profile and demographic information, such as cruise traveling experience, gender, age, marital status, annual income, educational status and living area by using distribution of frequency.

\section{Exploratory Factor Analysis (EFA)}

After 582 cases were inputted into SPSS 23 Version, an Exploratory Factor Analysis (EFA) was conducted on the planned behavior and motivation items. The purposes of EFA are to determine the proper number of common factors and explore which variables are indicators of the different latent factors (Beckman, 2013a; Brown, 2006; P. Wood, 2008). The exploratory factor analysis used the maximum likelihood extraction method with Varimax (orthogonal) rotation. Factor loading can be observed for an EFA of planned behavior items (from the Theory of Planned Behavior Scale) in Table 4. Factor loadings for the EFA of cruise traveling motivational items can be viewed in Table 5. 
Table 4. Factor loadings based on an exploratory factor analysis with Varimax (Orthogonal) rotation for 16 items from the Theory of Planned Behavior Scale $(\mathrm{N}=582)$

\begin{tabular}{|c|c|c|c|c|}
\hline Factor & & SN & PBC & ATT \\
\hline $\begin{array}{l}\text { Attitude } \\
\text { Towards } \\
\text { Behavior } \\
\text { (ATT) }\end{array}$ & $\begin{array}{l}\text { For me, cruising is pleasant. } \\
\text { For me, cruising is fun. } \\
\text { For me, cruising is enjoyable. } \\
\text { For me, cruising is valuable. } \\
\text { For me, cruising is interesting. } \\
\text { For me, cruising is safe. }\end{array}$ & & & $\begin{array}{l}0.651 \\
0.587 \\
0.514\end{array}$ \\
\hline $\begin{array}{l}\text { Subjective } \\
\text { Norm } \\
(\mathrm{SN})\end{array}$ & $\begin{array}{l}\text { I will participate in cruise travel because it is popular among my friends/family. } \\
\text { I will participate in cruise travel because my friends/family have talked a lot about it. } \\
\text { I will participate in cruise travel because it has been recommended by friends/family. } \\
\text { I will participate in cruise travel because my friends/family participated. } \\
\text { I will participate in cruise travel because my friends/family think it is good to } \\
\text { participate. }\end{array}$ & $\begin{array}{l}0.668 \\
0.814 \\
0.801 \\
0.836 \\
0.781\end{array}$ & & \\
\hline
\end{tabular}




\begin{tabular}{|l|l|c|c|}
\hline Perceived & I have enough time to participate in cruise travel. & 0.645 & 0.612 \\
Behavioral & I have enough money to participate in cruise travel. & 0.698 \\
Control & I have enough opportunities to participate in cruise travel. & 0.678 \\
(PBC) & I feel nothing will prevent me from participating in cruise travel if I want. & 0.698 & \\
\hline
\end{tabular}


Table 5. Factor loadings based on an exploratory factor analysis with Varimax (Orthogonal) rotation for 26 items of the Cruise Traveling Motivational Scale $(\mathrm{N}=582)$

\begin{tabular}{|c|c|c|c|c|c|}
\hline Factor & & SS & $\mathrm{SC}$ & EN & $\mathrm{FM}$ \\
\hline $\begin{array}{l}\text { Self-esteem \& Social } \\
\text { Recognition (SS) }\end{array}$ & $\begin{array}{l}\text { To do something that impresses others. } \\
\text { To help me feel like a better person. } \\
\text { To increase my feelings of self-worth. } \\
\text { To derive a feeling of accomplishment. } \\
\text { To photograph an exotic place to show friends. }\end{array}$ & $\begin{array}{l}0.712 \\
0.811 \\
0.817 \\
0.753 \\
0.585\end{array}$ & & & \\
\hline $\begin{array}{l}\text { Escape \& Relaxation } \\
(\mathrm{ER})\end{array}$ & $\begin{array}{l}\text { So that I can be free to do whatever I want. } \\
\text { To give my mind a rest. } \\
\text { I cruise to have fun. } \\
\text { To have more privacy than you have back home. } \\
\text { To get away from the usual demands of life. }\end{array}$ & & & & \\
\hline $\begin{array}{l}\text { Learning/Discovery } \\
\& \text { Thrill (LD) }\end{array}$ & $\begin{array}{l}\text { To gain knowledge. } \\
\text { To experience other cultures. } \\
\text { To discover something new. }\end{array}$ & & & & \\
\hline
\end{tabular}




\begin{tabular}{|l|l|l|l|l|}
\hline & To learn more about nature. & & 0.710 \\
\hline Creativity (CR) & $\begin{array}{l}\text { To be creative. } \\
\text { To do something creative such as diving, game changers, } \\
\text { marquee shows. } \\
\text { To gain a new perspective on life. }\end{array}$ & & & \\
\hline Socialization/Bonding & $\begin{array}{l}\text { Because my friends/family want to cruise. } \\
\text { To interact with friends/family. } \\
\text { (SC) }\end{array}$ & $\begin{array}{l}\text { Cruising provides me a chance to meet new people. } \\
\text { I cruise because I like to meet different people on a cruise ship. } \\
\text { To be with other who enjoy the same things you do. }\end{array}$ & 0.706 & 0.773 \\
\hline Enjoy Nature (EN) & $\begin{array}{l}\text { To view the scenic beauty. } \\
\text { To be close to nature (e.g. Ocean). } \\
\text { To enjoy the smells and sounds of nature. } \\
\text { To be where things are natural. }\end{array}$ & 0.776 & 0.697 \\
\hline
\end{tabular}


While the number of factors that represented cruise traveling motivation changed, the items that represent the Theory of Planned Behavior did not change. In the EFA of planned behavior items, there are only three items' factor loading lower than 0.50 but no cross loading. A table with the results of the EFA for planned behavior scales can be seen in Table 6. For the cruise traveling motivation, several factors, such as Escape \& Relaxation, Learning/Discovery \& Thrill and Creativity, loaded lower than 0.05 ; and "To learn more about nature" in factor Learning/Discovery \& Thrill cross loaded to factor Enjoy Nature. A table with the results of the EFA for the cruise traveling motivation scales can be seen in Table 7. In addition, the modified proposed path model (based upon the EFA results) can been seen in Figure 7 and a list of the renumbered hypotheses can be seen in Table 8. 
Table 6. Results of the planned behavior EFA factor loadings

\begin{tabular}{|c|c|c|c|c|}
\hline \multirow{2}{*}{ Factor } & & \multirow{2}{*}{$\begin{array}{c}\text { Result of EFA Factor } \\
\text { Loading }\end{array}$} & \multicolumn{2}{|c|}{ Reason if deleted } \\
\hline & & & $\begin{array}{c}\text { Low Factor } \\
\text { Loading } \\
(<0.50)\end{array}$ & $\begin{array}{c}\text { Cross } \\
\text { Loading }\end{array}$ \\
\hline ATT & $\begin{array}{l}\text { For me, cruising is pleasant. } \\
\text { For me, cruising is fun. } \\
\text { For me, cruising is enjoyable. } \\
\text { For me, cruising is valuable. } \\
\text { For me, cruising is interesting. } \\
\text { For me, cruising is safe. }\end{array}$ & $\begin{array}{l}\text { Included in the factor ATT } \\
\text { Included in the factor ATT } \\
\text { Eliminate from the model } \\
\text { Eliminate from the model } \\
\text { Included in the factor ATT } \\
\text { Eliminate from the model }\end{array}$ & $\begin{array}{l}\text { Yes } \\
\text { Yes } \\
\text { Yes }\end{array}$ & $\begin{array}{l}\text { No } \\
\text { No } \\
\text { No }\end{array}$ \\
\hline $\mathrm{SN}$ & $\begin{array}{l}\text { I will participate in cruise travel because it is popular among } \\
\text { my friends/family. } \\
\text { I will participate in cruise travel because my friends/family } \\
\text { have talked a lot about it. } \\
\text { I will participate in cruise travel because it has been } \\
\text { recommended by friends/family. }\end{array}$ & $\begin{array}{l}\text { Included in the factor SN } \\
\text { Included in the factor SN } \\
\text { Included in the factor SN } \\
\text { Included in the factor SN }\end{array}$ & & \\
\hline
\end{tabular}




\begin{tabular}{|l|l|l|l|}
\hline & $\begin{array}{l}\text { I will participate in cruise travel because my friends/family } \\
\text { participated. } \\
\text { I will participate in cruise travel because my friends/family } \\
\text { think it is good to participate. }\end{array}$ & Included in the factor SN \\
\hline PBC & $\begin{array}{l}\text { I have enough time to participate in cruise travel. } \\
\text { I have enough money to participate in cruise travel. } \\
\text { I have enough opportunities to participate in cruise travel. } \\
\text { I feel nothing will prevent me from participating in cruise } \\
\text { travel if I want. } \\
\text { If I want, I can easily participate in cruise travel. }\end{array}$ & Included in the factor PBC \\
Included in the factor PBC & Included in the factor PBC & \\
\hline
\end{tabular}


Table 7. Results of the cruise traveling motivation EFA factor loadings

\begin{tabular}{|c|c|c|c|c|}
\hline \multirow{2}{*}{ Factor } & & \multirow{2}{*}{$\begin{array}{c}\text { Result of EFA Factor } \\
\text { Loading }\end{array}$} & \multicolumn{2}{|c|}{ Reason if deleted } \\
\hline & & & $\begin{array}{c}\text { Low Factor } \\
\text { Loading } \\
(<0.50)\end{array}$ & $\begin{array}{c}\text { Cross } \\
\text { Loading }\end{array}$ \\
\hline SS & $\begin{array}{l}\text { To do something that impresses others. } \\
\text { To help me feel like a better person. } \\
\text { To increase my feelings of self-worth. } \\
\text { To derive a feeling of accomplishment. } \\
\text { To photograph an exotic place to show friends. }\end{array}$ & $\begin{array}{l}\text { Included in the factor SS } \\
\text { Included in the factor SS } \\
\text { Included in the factor SS } \\
\text { Included in the factor SS } \\
\text { Included in the factor SS }\end{array}$ & & \\
\hline ER & So that I can he free to do whatever I want & Eliminate from the model & Yes & $\mathrm{No}$ \\
\hline (Eliminate & To give my mind a rest. & Eliminate from the model & Yes & No \\
\hline from the & I cruise to have fun. & Eliminate from the model & Yes & No \\
\hline \multirow[t]{2}{*}{ model) } & To have more privacy than you have back home. & Eliminate from the model & Yes & No \\
\hline & To get away from the usual demands of life. & Eliminate from the model & Yes & No \\
\hline LD & To gain knowledge. & Eliminate from the model & Yes & Yes \\
\hline \multirow[t]{2}{*}{ (Eliminate } & To experience other cultures. & Eliminate from the model & Yes & Yes \\
\hline & To discover something new. & Eliminate from the model & Yes & Yes \\
\hline
\end{tabular}




\begin{tabular}{|c|c|c|c|c|}
\hline $\begin{array}{l}\text { from the } \\
\text { model) }\end{array}$ & To learn more about nature. & Included in the factor EN & No & Yes \\
\hline $\begin{array}{l}\text { CR } \\
\text { (Eliminate } \\
\text { from the } \\
\text { model) }\end{array}$ & $\begin{array}{l}\text { To be creative. } \\
\text { To do something creative such as diving, game changers, } \\
\text { marquee shows. } \\
\text { To gain a new perspective on life. }\end{array}$ & $\begin{array}{l}\text { Eliminate from the model } \\
\text { Eliminate from the model } \\
\text { Eliminate from the model }\end{array}$ & $\begin{array}{l}\text { Yes } \\
\text { Yes }\end{array}$ & $\begin{array}{l}\text { Yes } \\
\text { Yes }\end{array}$ \\
\hline $\mathrm{SC}$ & $\begin{array}{l}\text { Because my friends/family want to cruise. } \\
\text { To interact with friends/family. } \\
\text { Cruising provides me a chance to meet new people. } \\
\text { I cruise because I like to meet different people on a cruise } \\
\text { ship. } \\
\text { To be with other who enjoy the same things you do. }\end{array}$ & $\begin{array}{l}\text { Included in the new factor } \\
\text { Included in the new factor } \\
\text { FM } \\
\text { Included in the factor SC } \\
\text { Included in the factor SC } \\
\text { Included in the factor SC }\end{array}$ & $\begin{array}{l}\text { No } \\
\text { No }\end{array}$ & $\begin{array}{l}\text { Yes } \\
\text { Yes }\end{array}$ \\
\hline EN & $\begin{array}{l}\text { To view the scenic beauty. } \\
\text { To be close to nature (e.g. Ocean). } \\
\text { To enjoy the smells and sounds of nature. }\end{array}$ & $\begin{array}{l}\text { Included in the factor EN } \\
\text { Included in the factor EN } \\
\text { Included in the factor EN }\end{array}$ & & \\
\hline
\end{tabular}




\begin{tabular}{|l|l|l|l|l|}
\hline To be where things are natural. & Included in the factor EN & & \\
\hline
\end{tabular}

\section{Modified Proposed Path Model and hypotheses}

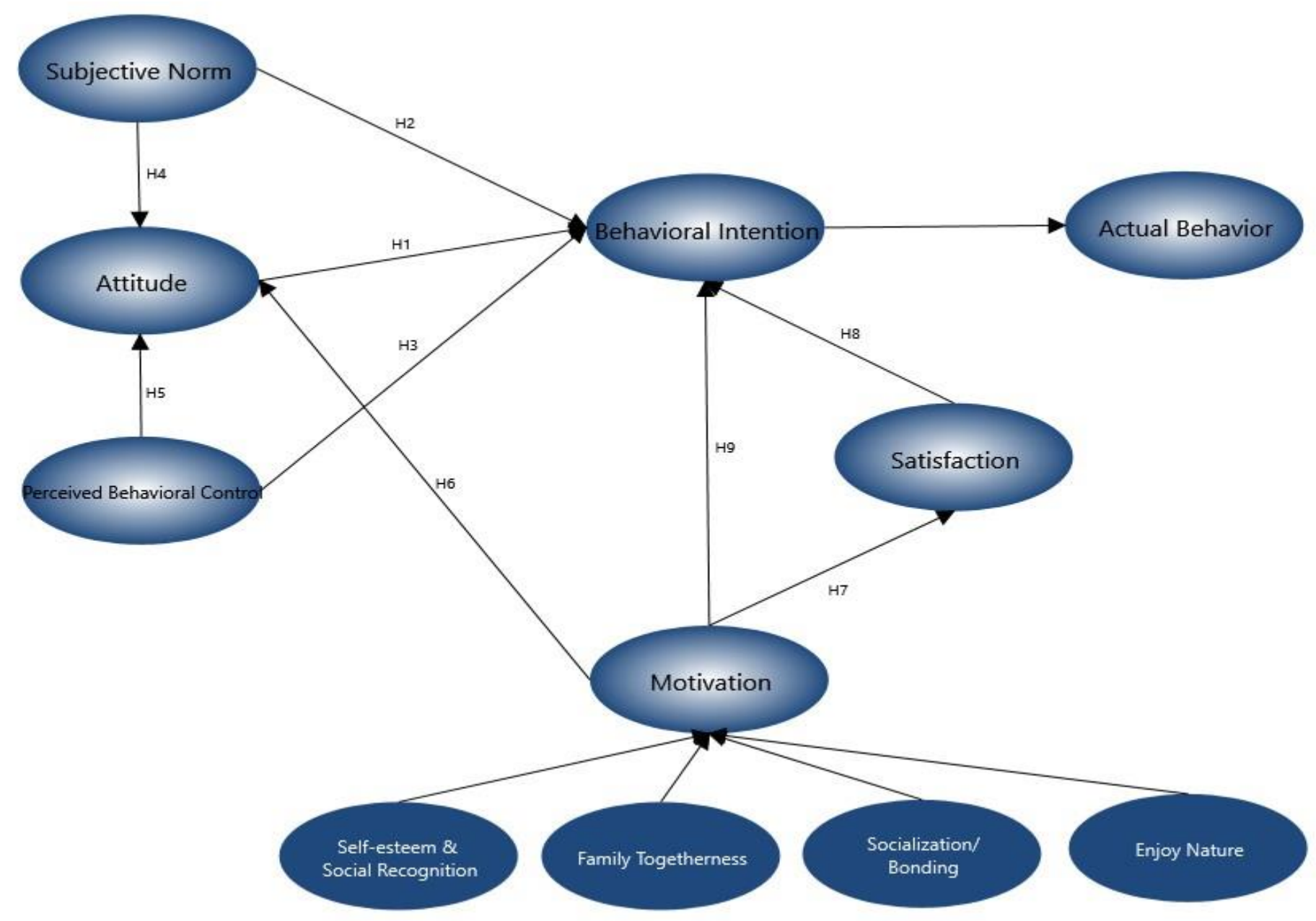

Figure 7. Modified Proposed Path Model 
Table 8. Hypotheses in Modified Proposed Path Model

\begin{tabular}{|l|l|}
\hline Hypotheses & $\begin{array}{l}\text { Chinese cruise travel attitudes exert a positive influence upon Chinese } \\
\text { cruise travel intention. }\end{array}$ \\
\hline H1 & $\begin{array}{l}\text { Subjective norms have a positive effect on Chinese cruise travel } \\
\text { intention. }\end{array}$ \\
\hline H3 & $\begin{array}{l}\text { Perceived behavior control positively influences Chinese cruise travel } \\
\text { intention. }\end{array}$ \\
\hline H4 & $\begin{array}{l}\text { Subjective norms have a positive effect on Chinese cruise travel } \\
\text { attitude. }\end{array}$ \\
\hline H5 & $\begin{array}{l}\text { Perceived behavior control positively influences Chinese cruise travel } \\
\text { attitude. }\end{array}$ \\
\hline H6 & $\begin{array}{l}\text { Chinese cruise travel motivation has a positive effect on Chinese cruise } \\
\text { travel attitude. }\end{array}$ \\
\hline H7 & $\begin{array}{l}\text { Chinese cruise travel motivation has a positive effect on Chinese cruise } \\
\text { travel satisfaction. }\end{array}$ \\
\hline H8 & $\begin{array}{l}\text { Chinese cruise travel satisfaction positively influences Chinese cruise } \\
\text { travel intention. }\end{array}$ \\
\hline H9 & $\begin{array}{l}\text { Chinese cruise travel motivation positively directly affects Chinese } \\
\text { cruise travel intention. }\end{array}$ \\
\hline
\end{tabular}


Based on the results of the EFA, three measurement items in factor ATT were eliminated because of low factor loading, and the researcher eliminated three factors in cruise traveling motivation scale due to low factor loading and cross-loading. Eliminating low loading and cross loading factors only changed the cruise traveling motivation part in the proposed model and the hypotheses remained the same.

\section{Confirmatory Factor Analysis (CFA)}

As discussed above, previous researchers commonly applied the EFA into situations where the factorial constructs of an instrument for an unknown population and usually to develop new instruments (Wang \& Wang, 2012). In contrast, the CFA has been applied to situations that previous researchers have some knowledge of the dimensionality

of the variable under study based on a created theory (Bollen, 1989; Brown, 2006; Wang \& Wang, 2012). The purpose of using the CFA in this study is to determine and confirm that the planned behavioral and motivational constructs of the whole cruise traveling instrument are as hypothesized.

By conducting the CFA in structural equation modeling, researchers are required to assess model fit and construct validity. Model fit is evaluating the measurement of model by several indices, and construct validity offers confidence that construct items are measured from a sample represent the actual true score that exist in the population (Hair, Black, Babin, \& Anderson, 2006; Liu, 2019). Bagozzi \& Yi (1988) suggested Cronbach's alpha, Factor loadings, Composite reliability (CR), Convergent and discriminant validity, Average Variance Extracted (AVE), and The Squared Multiple Correlations (SMCs) as common indicators of testing construct validity in the CFA. The SPSS 23 Version has been 
used to process the CFA and the information of each indicator is briefly introduced in the following paragraph.

Cronbach's alpha is used to evaluate the reliability in an integrative scale, indicating measurements internal consistency. The Cronbach's alpha coefficient greater than 0.70 implies high reliability (Cronbach \& Shavelson, 2004; Liu, 2019). Factor loadings of constructs and structures were examined to determine the statistical significances in the model, and Hair et al. (2006) suggested a cutoff of 0.50 for factor loadings. Composite reliability (CR) needs to be calculated for each latent variable in SEM to examine whether observed variables could measure latent variables efficaciously. A composite reliability value greater than 0.60 is considered acceptable (Fornell \& Larcker, 1981). Convergent validity considers the similarity among measures within a factor, and discriminant validity considers the divergence between measures for different constructs (Liu, 2019; Trochim, 2010). Average variance extracted (AVE) was applied commonly for evaluating convergent validity and reliability of constructs in SEM. The AVE of each construct should exceed 0.50 to ensure convergent validity and be greater than the respective correlation estimate among constructs to ensure discriminant validity (Fornell \& Larcker, 1981; Liu, 2019). The squared multiple correlations (SMCs) of the exogenous and endogenous variables show how well the measurement items measure the latent construct. The range of SMCs is from 0 to 1 , and the values that closer to 1 implying a better measurement of the latent construct (Liu, 2019; Reisinger \& Turner, 1999).

\section{Structural Equation Modelling (SEM)}

Structural equation modeling (SEM) is originally from factor analysis and simultaneous equations (Spearman, 1987; Tucker, 1955). Within the development of 
research methodology, factor analysis and path analysis have been integrated to a more generalized analytical framework, called SEM (Jöreskog, 1967; K. G. Joreskog \& Sorbom, 1982; Tabri \& Elliott, 2012). According to former studies, researchers estimated constructs or factors from observed indicator variables, and the estimation of the relations between the latent variables free of the influence of measurement errors is a focus in recent SEM research (Bentler, 1990; Bentler \& Bonett, 1980; Bollen, 1989; K. G. Joreskog \& Sorbom, 1982). In this study, Theory of Planned Behavior constructs and Cruise Traveling Motivation factors are estimated from measurement items, and the purpose of running SEM is to explore the relationship between factors in the instrument. The SPSS AMOS version 23 structural equation analysis package was used to conduct the analysis.

Testing model fit is important and necessary in SEM, including model fitness analysis and model interpretation. The purpose of structural model analysis is to determine the effects of variables simultaneously rather than separately. Furthermore, there are a variety of criteria to analyze the fitness of a model. Table 9 presented the frequently used model fit indices (criteria) which was applied to this study.

Reliability and validity analyses in CFA are also conducted for SEM, including factor loadings, composite reliability (CR), average variance extracted (AVE), and the squared multiple correlations (SMCs). The judging criteria of value for each indicator are the same as discussed above in CFA. 
Table 9. Frequently Used Model Fit Indices

\begin{tabular}{|c|l|l|}
\hline Measure & \multicolumn{1}{|c|}{ Description } & \multicolumn{1}{|c|}{ Fit Guideline } \\
\hline CMIN/DF & $\begin{array}{l}\text { The minimum discrepancy divided by its } \\
\text { degrees of freedom (M. W. Browne, 1984). }\end{array}$ & $\begin{array}{l}\text { Terrible: }>5 \\
\text { Acceptable: }>3 \\
\text { Excellent: }>1\end{array}$ \\
\hline CFI & $\begin{array}{l}\text { Comparative fit index equation: } \\
C F I=1-\frac{\max \left[\left(x_{t}^{2}-v_{t}\right), 0\right]}{\max \left[\left(x_{t}^{2}-v_{t}\right),\left(x_{i}^{2}-v_{i}\right), 0\right]}\end{array}$ & \\
$\begin{array}{l}\text { Both } \chi_{\mathrm{i}} \text { and } \chi_{\mathrm{t}} \text { are test statistics of the } \\
\text { independence model and the target model } \\
\text { respectively. } \mathrm{V}_{\mathrm{i}} \text { and } \mathrm{v}_{\mathrm{t}} \text { are the degrees of } \\
\text { freedom of the independence model and the } \\
\text { target model in relation to chi-square test } \\
\text { statistics respectively (Bentler, 1990; Cangur } \\
\& \text { Ercan, 2015). }\end{array}$ & $\begin{array}{l}\text { Terrible: }<0.90 \\
\text { Acceptable: }<0.95 \\
\text { Excellent: }>0.95\end{array}$ \\
\hline SRMR & $\begin{array}{l}\text { The square-root of the difference between } \\
\text { the residuals of the sample covariance matrix } \\
\text { and the hypothesized model (Bentler, 1990; } \\
\text { Liu, 2019). }\end{array}$ & $\begin{array}{l}\text { Terrible: }>0.10 \\
\text { Acceptable: }>0.08 \\
\text { Excellent: }<0.08\end{array}$ \\
\hline RMSEA & $\begin{array}{l}\text { Root mean square error of approximation } \\
\text { (Michael W. Browne \& Cudeck, 1992). }\end{array}$ & $\begin{array}{l}\text { Terrible: }>0.08 \\
\text { Acceptable: }>0.06 \\
\text { Excellent: }<0.06\end{array}$ \\
\hline PClose & $\begin{array}{l}\text { "p value" for testing the null hypothesis that } \\
\text { the population RMSEA is no greater than } \\
\text { 0.05 (M. W. Browne, 1984). }\end{array}$ & $\begin{array}{l}\text { Terrible: }<0.01 \\
\text { Acceptable: }<0.05 \\
\text { Excellent: }>0.05\end{array}$ \\
\hline
\end{tabular}




\section{CHAPTER 4: RESULTS}

This chapter discussed the results of the data analysis and hypotheses testing, including five sections: Data Screening, Demographic Profile of the Respondents, Results of Confirmatory Factor Analysis (CFA), Structural Equation Evaluation, and Hypotheses Testing. In order to determine the measurement items for each construct are suitably placed, CFA has been done to the collected data. Furthermore, the research model and proposed hypotheses were tested using SEM. Both the CFA and the SEM were launched by using SPSS AMOS version 23. Moreover, maximum likelihood estimation was used for both the CFA and SEM.

\section{Data Screening}

The researcher analyzed data by using the statistical software SPSS version 23, and data screening of outliers and normal distributions were conducted to prepare collected data for descriptive analysis, confirmatory factor analysis, and structural equation modeling. Respondents were not allowed to skip any questions in the survey, so there are no missing values in the collected data. Table 10 presented the results of missing value check in SPSS. Moreover, the design of this study is not required to split samples.

Table 10. Result of Missing Value Check

\begin{tabular}{|c|c|c|c|c|c|c|c|c|c|c|c|c|c|c|c|c|}
\hline \multicolumn{17}{|c|}{ Statistics } \\
\hline & & $\mathrm{NO}$ & ATT & SN & $\mathrm{PBC}$ & SS & ER & LD & CR & FM & $\mathrm{SC}$ & EN & TS & INT & CPP & PI \\
\hline $\mathrm{N}$ & Valid & 573 & 573 & 573 & 573 & 573 & 573 & 573 & 573 & 573 & 573 & 573 & 573 & 573 & 573 & 573 \\
\hline & Missing & 0 & 0 & 0 & 0 & 0 & 0 & 0 & 0 & 0 & 0 & 0 & 0 & 0 & 0 & 0 \\
\hline
\end{tabular}

The definition of outlier is "a raw score on the offending variable that is one unit larger (smaller) than the next most extreme score in the distribution" (Tabachnick \& Fidell, 
2007). More commonly, the outlier affects both results and assumptions in research (Yuan \& Zhong, 2013), therefore, this study applied two ways to identify and remove outliers. First of all, z-score analysis were calculated in SPSS version 23, and items with a z-score exceeding \pm 3.29 ( $\mathrm{p}<0.001$, two tailed test) need to be identified as outlier and deleted (Liu, 2019). The range of $z$-score in the collected data is -2.926 to 2.945 , so no outlier were identified in this analysis. Secondly, Mahalanobis distance was tested in AMOS version 23 for normality and outliers. A point that has a greater Mahalanobis distance from the rest of the sample population of points is said to have higher leverage since it has a greater influence on the slope or coefficients of the regression equation (Blatná, 2014; Seheult, Green, Rousseeuw, \& Leroy, 1989). Samples with high Mahalanobis d-square (> 95) has been deleted, and 573 respondents are remained in the dataset.

\section{Demographic Profile of the Respondents}

Before investigating the research constructs, the demographic and cruise preferences profile of the respondents were tested to provide some contextual information and to accomplish Objective 1 in Chapter 5. Among the 573 respondents, $40.8 \%$ were male, and $59.2 \%$ were female. $78.9 \%$ of respondents are married, and most of the respondents are between 22 and 44 years old, representing $86.7 \%$ of the total population. Seventy two point eight percent of the respondents hold a Bachelor's degree, and $21.1 \%$ are in the Master and Doctoral level. In terms of annual income, $0.9 \%$ of respondents had less than RMB 50,000; 5.8\% of respondents had between RMB 50,000 and RMB 99,999 in total annual income; $13.6 \%$ of respondents had between RMB 100,000 and RMB 149,999 in total annual income; $12.9 \%$ of respondents had between RMB 150,000 and RMB 199,999 in total annual income; $23.9 \%$ of respondents had between RMB 200,000 and RMB 
249,999 in total annual income; $14.8 \%$ of respondents had between RMB 250,000 and RMB 299,999 in total annual income; $11.7 \%$ of respondents had between RMB 300,000 and RMB 349,999 in total annual income; and 16.4\% of respondents had over RMB 350,000 totally in a year. Respondents who earned over RMB 200,000 annually (66.8\%) considered cruise traveling more based on the demographic frequency analysis. Moreover, the majority of respondents live in North China (Beijing, Tianjin, Hebei, Shanxi, Inner Mongolia), East China (Shanghai, Jiangsu, Zhejiang, Anhui, Fujian, Jiangxi, Shandong), and Central and South (Henan, Hubei, Hunan, Guangdong, Guangxi, Hainan, HK, Macau). These three regions account for $88.8 \%$ in total. Table 11 presented respondents' demographic profile. 
Table 11. Respondents' Demographic Profile

\begin{tabular}{|c|c|c|c|}
\hline Characteristics & Categories & $\begin{array}{l}\text { Frequency } \\
\text { (N) }\end{array}$ & $\begin{array}{c}\text { Percentage } \\
(\%)\end{array}$ \\
\hline \multirow{2}{*}{$\begin{array}{l}\text { 1. Have you travelled } \\
\text { with cruise line? } \\
(\mathrm{N}=573)\end{array}$} & Yes & 573 & 100.0 \\
\hline & No & 0 & 0.0 \\
\hline \multirow{2}{*}{ 2. Gender $(\mathrm{N}=573)$} & Male & 234 & 40.8 \\
\hline & Female & 339 & 59.2 \\
\hline \multirow{3}{*}{$\begin{array}{l}\text { 3. Marital status } \\
(\mathrm{N}=573)\end{array}$} & Single & 119 & 20.8 \\
\hline & Married & 452 & 78.9 \\
\hline & With partner & 2 & 0.3 \\
\hline \multirow{6}{*}{ 4. Age (years) $(\mathrm{N}=573)$} & $21-24$ & 47 & 8.2 \\
\hline & $25-34$ & 325 & 56.7 \\
\hline & $35-44$ & 172 & 30.0 \\
\hline & $45-54$ & 25 & 4.4 \\
\hline & $55-64$ & 3 & 0.5 \\
\hline & $65+$ & 1 & 0.2 \\
\hline \multirow{8}{*}{$\begin{array}{l}\text { 5. Annual income } \\
(\mathrm{N}=573)\end{array}$} & RMB 50,000 or less & 5 & 0.9 \\
\hline & $\begin{array}{l}\text { RMB 50,000 - RMB 99,999 } \\
\text { RMB 100,000 - RMB }\end{array}$ & 33 & 5.8 \\
\hline & $\begin{array}{l}149,999 \\
\text { RMB } 150,000 \text { - RMB }\end{array}$ & 78 & 13.6 \\
\hline & $\begin{array}{l}199,999 \\
\text { RMB 200,000 - RMB }\end{array}$ & 74 & 12.9 \\
\hline & $\begin{array}{l}249,999 \\
\text { RMB 250,000 - RMB }\end{array}$ & 137 & 23.9 \\
\hline & $\begin{array}{l}299,999 \\
\text { RMB 300,000 - RMB }\end{array}$ & 85 & 14.8 \\
\hline & 349,999 & 67 & 11.7 \\
\hline & RMB 350,000 or more & 94 & 16.4 \\
\hline \multirow{6}{*}{ 6. Living area $(\mathrm{N}=573)$} & North China & 109 & 19.0 \\
\hline & Northeast & 31 & 5.4 \\
\hline & East China & 234 & 40.8 \\
\hline & Central and South & 166 & 29.0 \\
\hline & Southwest & 25 & 4.4 \\
\hline & Northwest & 8 & 1.4 \\
\hline \multirow{6}{*}{ 7. Education $(\mathrm{N}=573)$} & High school & 2 & 0.3 \\
\hline & Associate degree & 33 & 5.8 \\
\hline & Bachelor's degree & 417 & 72.8 \\
\hline & Master's degree & 117 & 20.4 \\
\hline & Doctoral degree & 4 & 0.7 \\
\hline & Other education/trade & 0 & 0 \\
\hline
\end{tabular}


Frequency analysis was done for cruise experience questions in the survey. Twenty three point six percent of respondents only participated in cruise traveling once in recent 10 years; $42.1 \%$ of respondents traveled with cruise twice in the past 10 years; $22.5 \%$ of respondents have been done cruise traveling three times in recent 10 years; and only $11.8 \%$ of respondents traveled with cruise more than 3 times in recent 10 years. Table 12 presented the cruise experience (times) frequency analysis.

Table 12. Cruise Experience (Times) Frequency Analysis

\begin{tabular}{|c|c|c|c|c|}
\hline Characteristics & Categories & Times & $\begin{array}{c}\text { Frequency } \\
(\mathbf{N})\end{array}$ & $\begin{array}{c}\text { Percentage } \\
(\%)\end{array}$ \\
\hline \multirow{17}{*}{$\begin{array}{l}\text { 1. Have you travelled } \\
\text { with cruise line? } \\
(\mathrm{N}=573)\end{array}$} & \multirow{17}{*}{ Yes } & 1 & 135 & 23.6 \\
\hline & & 2 & 241 & 42.1 \\
\hline & & 3 & 129 & 22.5 \\
\hline & & 4 & 20 & 3.5 \\
\hline & & 5 & 22 & 3.8 \\
\hline & & 6 & 9 & 1.6 \\
\hline & & 7 & 4 & 0.7 \\
\hline & & 8 & 2 & 0.3 \\
\hline & & 9 & 1 & 0.2 \\
\hline & & 10 & 3 & 0.5 \\
\hline & & 11 & 1 & 0.2 \\
\hline & & 13 & 1 & 0.2 \\
\hline & & 15 & 2 & 0.3 \\
\hline & & 16 & 1 & 0.2 \\
\hline & & 18 & 1 & 0.2 \\
\hline & & 19 & 1 & 0.2 \\
\hline & & Total & 573 & 100.0 \\
\hline
\end{tabular}

The histogram of cruise experience (times) has been created based on the frequency analysis. Figure 8 presented the cruise experience (times) histogram. This histogram indicated that most of the Chinese cruise travelers participated in cruise traveling 1 to 3 times in the past decade. The cruise industry is still developing; however, as the consumers 
start accepting cruise culture more, the outlook for the future of the cruise industry in China is optimistic.

Figure 8. Cruise Experience (Times) Histogram

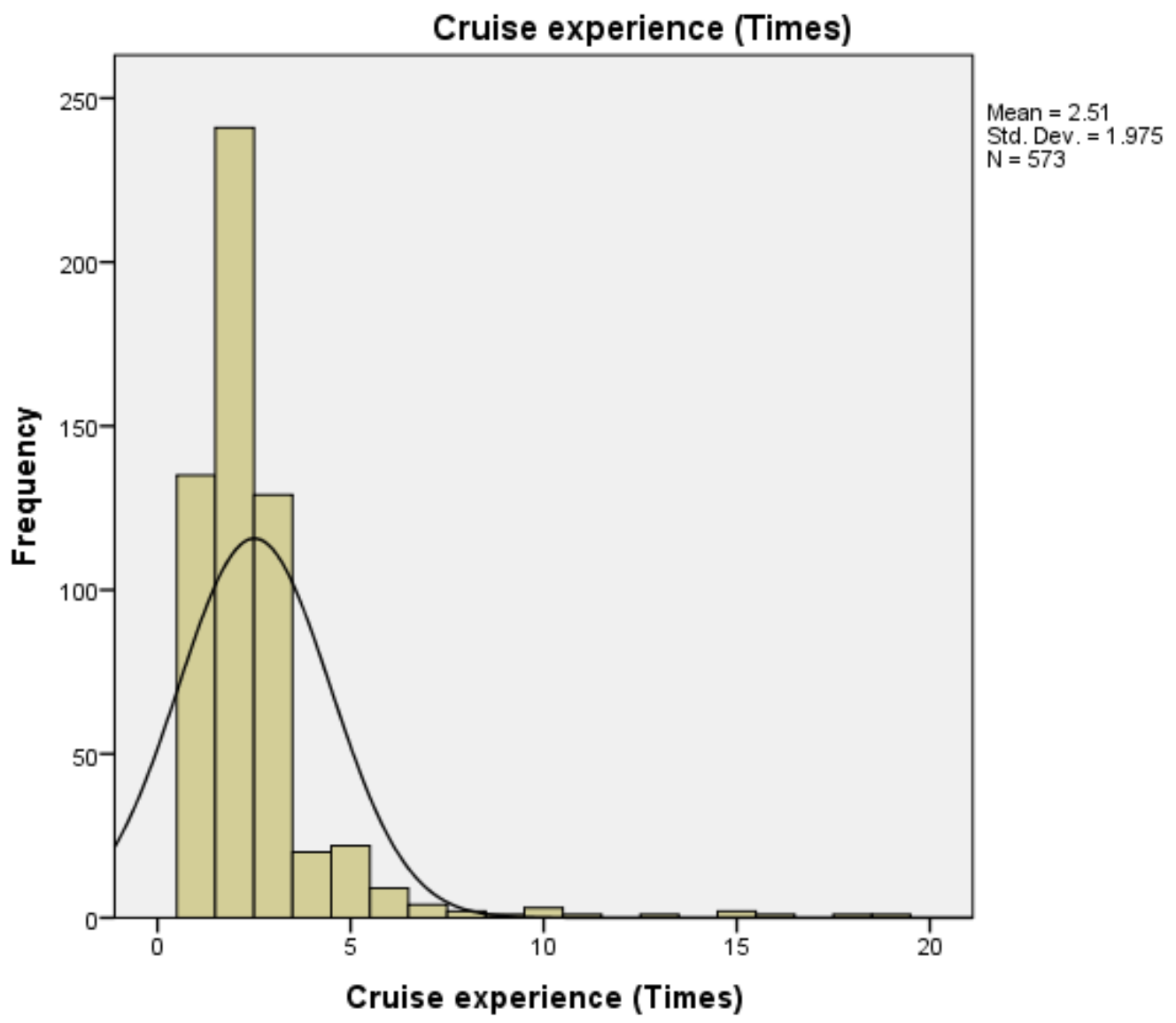

Table 13 presented the cruise preferences profile of this study. Respondents prefer traveling via cruise to Japan (66.1\%), Europe (62.1\%), and Southeast Asia (58.5\%) the most. Surprisingly, less than $50 \%$ of respondents prefer participating in cruise traveling to Korea, which was the most attractive cruise destination in the past. A variety of travelplanning time horizons were reported, with 1 to 2 months $(50.4 \%)$ in advance being the most popular. Online travel agency $(70.7 \%)$ is the most likely channel for booking a cruise, followed by cruise company $(20.8 \%)$. Compared to the results of previous studies, the favorite cruise booking channel has changed to online travel agencies and cruise companies 
from traditional travel agencies (Fan \& Hsu, 2014). As for cruise duration, 7 to 9 days (44.2\%) was the most preferred option, followed by 4 to 6 days (33.0\%) and 10 to 15 days $(16.4 \%)$.

Table 13. Cruise Preferences Profile

\begin{tabular}{|c|c|c|c|}
\hline \multicolumn{4}{|c|}{ What is(are) your most preferred cruise destination(s)? } \\
\hline Southeast Asia & $58.5 \%$ & Japan & $66.1 \%$ \\
\hline Europe & $62.1 \%$ & North America & $25.0 \%$ \\
\hline Korea & $42.9 \%$ & None & $1.9 \%$ \\
\hline Middle East & $10.6 \%$ & Others() & $1.0 \%$ \\
\hline \multicolumn{4}{|c|}{ How far in advance would you begin planning your cruise travel? } \\
\hline Less than a month & $12.2 \%$ & 5-6 months & $5.6 \%$ \\
\hline 1-2 months & $50.4 \%$ & More than 6 months & $3.0 \%$ \\
\hline 3-4 months & $28.8 \%$ & & \\
\hline \multicolumn{4}{|c|}{ What is your most preferred cruise booking channel? } \\
\hline Online travel agencies & $70.7 \%$ & Cruise companies & $20.8 \%$ \\
\hline Traditional travel agencies & $8.2 \%$ & Others() & $0.3 \%$ \\
\hline \multicolumn{4}{|c|}{ What is your most preferred cruise duration? } \\
\hline $1-3$ days & $3.8 \%$ & 10-15 days & $16.4 \%$ \\
\hline 4-6 days & $33.0 \%$ & More than 15 days & $2.6 \%$ \\
\hline 7-9 days & $44.2 \%$ & & \\
\hline
\end{tabular}

Table 14 presented the descriptive statistics of all remaining measurement items from EFA. In this step, tests for normality were performed to measure variability, and other descriptive indicators that were recorded include mean, standard deviation, skewness, and kurtosis. For determining if there is an instance of non-normality, the threshold of 7 Kurtosis distribution was used (Beckman, 2013b; M. E. Byrne, 2006). In addition, Kurtosis distribution should always be addressed when using SEM due to the possibility of its effect on tests of variances and covariances (Decarlo, 1997). The results showed that none of the values of kurtosis exceeded the threshold of 7 . 
Table 14. Descriptive Statistics of Measurement Items

\begin{tabular}{|c|c|c|c|c|}
\hline Factor & Mean & STD & Skewness & Kurtosis \\
\hline \multicolumn{5}{|l|}{ Attitude } \\
\hline For me, cruising is pleasant. & 6.22 & .717 & -.695 & .534 \\
\hline For me, cruising is fun. & 6.25 & .770 & -.829 & .506 \\
\hline For me, cruising is interesting. & 6.04 & .837 & -.796 & .559 \\
\hline \multicolumn{5}{|l|}{ Subjective Norm } \\
\hline I will participate in cruise travel because it is popular among my friends/family. & 4.61 & 1.425 & -.394 & -.389 \\
\hline I will participate in cruise travel because my friends/family have talked a lot about it. & 4.98 & 1.425 & -.648 & -.053 \\
\hline I will participate in cruise travel because it has been recommended by friends/family. & 5.05 & 1.430 & -.770 & .102 \\
\hline I will participate in cruise travel because my friends/family participated. & 5.21 & 1.560 & -.972 & .145 \\
\hline $\begin{array}{l}\text { I will participate in cruise travel because my friends/family think it is good to } \\
\text { participate. }\end{array}$ & 5.22 & 1.461 & -.939 & .467 \\
\hline \multicolumn{5}{|l|}{ Perceived Behavioral Control } \\
\hline I have enough time to participate in cruise travel. & 5.38 & 1.175 & -.748 & .567 \\
\hline I have enough money to participate in cruise travel. & 5.77 & 1.111 & -.865 & .573 \\
\hline I have enough opportunities to participate in cruise travel. & 5.41 & 1.222 & -.834 & .638 \\
\hline I feel nothing will prevent me from participating in cruise travel if I want. & 4.67 & 1.465 & -.405 & -.549 \\
\hline If I want, I can easily participate in cruise travel. & 5.45 & 1.215 & -.901 & 1.031 \\
\hline \multicolumn{5}{|l|}{ Self-esteem \& Social Recognition } \\
\hline To do something that impresses others. & 3.59 & 1.562 & .328 & -.654 \\
\hline To help me feel like a better person. & 3.88 & 1.593 & .018 & -.782 \\
\hline To increase my feelings of self-worth. & 4.13 & 1.606 & -.161 & -.814 \\
\hline To derive a feeling of accomplishment. & 4.19 & 1.565 & -.211 & -.625 \\
\hline $\begin{array}{l}\text { To photograph an exotic place to show friends. } \\
\text { Socialization/Bonding }\end{array}$ & 4.56 & 1.633 & -.293 & -.622 \\
\hline Cruising provides me a chance to meet new people. & 5.02 & 1.278 & -.469 & .186 \\
\hline I cruise because I like to meet different people on a cruise ship. & 4.82 & 1.448 & -.380 & -.319 \\
\hline
\end{tabular}


To be with other who enjoy the same things you do.

$\begin{array}{cccc}4.56 & 1.412 & -.340 & -.266 \\ & & & \\ 6.15 & .879 & -1.050 & 1.105 \\ 5.95 & 1.018 & -.917 & .607 \\ 5.94 & .952 & -.956 & 1.150 \\ 5.76 & 1.055 & -.942 & 1.244 \\ 5.91 & 1.071 & -.963 & .585 \\ & & & \\ 4.37 & 1.411 & -.215 & -.560 \\ 4.57 & 1.556 & -.485 & -.466 \\ & & & \\ 6.02 & .782 & -.725 & 1.164 \\ 5.83 & 1.006 & -.850 & .767 \\ 5.43 & 1.053 & -.493 & .263 \\ & & & \\ 5.40 & 1.143 & -.653 & .552 \\ & & & \\ & & & .638 \\ 5.69 & .858 & -.436 & 1.072 \\ 5.87 & .978 & -.838 & 1.169 \\ 5.80 & 1.065 & -.944 & .238 \\ 4.95 & 1.262 & -.546 & .774 \\ 5.24 & 1.195 & -.775 & \end{array}$

Enjoy Nature

To view the scenic beauty.

To be close to nature (e.g. Ocean).

To enjoy the smells and sounds of nature.

To be where things are natural.

To learn more about nature.

Family Togetherness

Because my friends/family want to cruise.

To interact with friends/family.

Travel Satisfaction

Overall, I am satisfied with my experience with cruise traveling.

Overall, cruise traveling worth my time and effort.

Overall, cruise traveling is much better than what I expected.

Overall, cruise traveling as a vacation option is much better than similar options

(flight, train, etc.).

Intention

I'll encourage friends/family to participate in cruise travel.

I want to participate in cruise travel within 12 months.

I intend to cruise on special day in the future (e.g. birthday, anniversary, etc.).

Cruise traveling is my first choice for traveling in the future.

I will save time and money within 12 months for participating in cruise travel.

5.24

Likert scale: (1 - Strongly Disagree, 7 - Strongly Agree) 
For most of respondents, cruising is fun $(M=6.25)$ and pleasant $(M=6.22)$. Respondents agreed that "I will participate in cruise travel because my friends/family participated" $(\mathrm{M}=5.21)$ and "I will participate in cruise travel because my friends/family think it is good to participate" $(M=5.22)$ mostly in Subjective Norm. "I have enough money to participate in cruise travel" $(M=5.77)$ showed the highest mean in Perceived Behavioral Control and they want to participate in cruise travel within 12 months $(M=5.87)$, indicating that Chinese consumers have enough money to cruise within the development of economy. According to the mean value of motivation measurement items, nature scenery motivated most of respondents to participate in cruise traveling, followed by socialization and bonding. Furthermore, most respondents are satisfied with their cruise traveling experience $(\mathrm{M}=6.02)$.

\section{Results of Confirmatory Factor Analysis (CFA)}

CFA was conducted for each construct followed by the testing of the overall measurement model. High modification indices provide evidence of misfit (Joreskog \& Sorbom, 1993). There is no specific threshold number to target, however, researchers caution against over fitting the model via the correlation of too many error terms (Byrne, 2009; Wheaton, 1987). When examining the modification indices, two pairs of error variance showed indices higher than 25: e4 <--> e5 (35.929), and e25 <--> e26 (28.433). Only these error covariances with a strong theoretical reasoning in the model to add such covariance were included. Table 15 presented the initial measurement model fit and measurement model fit after adding error covariances (Final measurement model). 
Table 15. Fit Statistics for Each Construct - Refined Model

\begin{tabular}{|c|c|c|c|c|c|}
\hline Model & CMIN/DF & CFI & SRMR & RMSEA & PClose \\
\hline Initial Measurement Model & 2.557 & 0.908 & 0.076 & 0.052 & 0.129 \\
\hline Final Measurement Model & 2.436 & 0.916 & 0.075 & 0.050 & 0.472 \\
\hline Threshold & Between 1 to 3 & $\geq .90$ & $<.08$ & $<.06$ & $>.05$ \\
\hline
\end{tabular}

The fit indices for the final results indicated a well-fitted model for the constructs. Furthermore, this study performed checks for validity and reliability. The final measurement model featured 9 constructs measuring 27 observed variables. The items had factor loadings ranging from 0.51 to 0.90 and all paths were significant $(\mathrm{p}<0.001)$. The composite reliabilities of each construct ranged from 0.630 to 0.891 , all meeting the minimum 0.70 criteria except for ATT ( $\mathrm{CR}=0.630$ ) (Hair et al., 2006). Table 16 presented the factor loadings and the composite reliabilities of constructs for the final measurement model. 
Table 16. Factor Loadings and Composite Reliabilities of the Final Measurement Model

\begin{tabular}{|c|c|c|c|}
\hline Construct & Scale Items & $\begin{array}{c}\text { Factor } \\
\text { Loading }\end{array}$ & $\begin{array}{l}\text { Composite } \\
\text { Reliability }\end{array}$ \\
\hline \multirow{3}{*}{ ATT } & For me, cruising is pleasant. & 0.68 & \multirow{3}{*}{0.630} \\
\hline & For me, cruising is fun. & 0.61 & \\
\hline & For me, cruising is interesting. & 0.51 & \\
\hline \multirow{5}{*}{$\mathrm{SN}$} & I will participate in cruise travel because it is popular among my friends/family. & 0.74 & \multirow{5}{*}{0.891} \\
\hline & I will participate in cruise travel because my friends/family have talked a lot about it. & 0.86 & \\
\hline & I will participate in cruise travel because it has been recommended by friends/family. & 0.81 & \\
\hline & I will participate in cruise travel because my friends/family participated. & 0.77 & \\
\hline & I will participate in cruise travel because my friends/family think it is good to participate. & 0.75 & \\
\hline \multirow{5}{*}{$\mathrm{PBC}$} & I have enough time to participate in cruise travel. & 0.69 & \multirow{5}{*}{0.831} \\
\hline & I have enough money to participate in cruise travel. & 0.67 & \\
\hline & I have enough opportunities to participate in cruise travel. & 0.75 & \\
\hline & I feel nothing will prevent me from participating in cruise travel if I want. & 0.69 & \\
\hline & If I want, I can easily participate in cruise travel. & 0.71 & \\
\hline \multirow{5}{*}{ SS } & To do something that impresses others. & 0.80 & \multirow{5}{*}{0.887} \\
\hline & To help me feel like a better person. & 0.88 & \\
\hline & To increase my feelings of self-worth. & 0.80 & \\
\hline & To derive a feeling of accomplishment. & 0.73 & \\
\hline & To photograph an exotic place to show friends. & 0.68 & \\
\hline \multirow{5}{*}{ EN } & To view the scenic beauty. & 0.69 & \multirow{5}{*}{0.865} \\
\hline & To be close to nature (e.g. Ocean). & 0.78 & \\
\hline & To enjoy the smells and sounds of nature. & 0.73 & \\
\hline & To be where things are natural. & 0.79 & \\
\hline & To learn more about nature. & 0.75 & \\
\hline $\mathrm{SC}$ & Cruising provides me a chance to meet new people. & 0.80 & 0.869 \\
\hline
\end{tabular}




\begin{tabular}{|c|c|c|c|}
\hline & I cruise because I like to meet different people on a cruise ship. & 0.85 & \\
\hline & To be with other who enjoy the same things you do. & 0.84 & \\
\hline \multirow{2}{*}{ FM } & Because my friends/family want to cruise. & 0.90 & \multirow{2}{*}{0.872} \\
\hline & To interact with friends/family. & 0.86 & \\
\hline \multirow{4}{*}{ TS } & Overall, I am satisfied with my experience with cruise traveling. & 0.68 & \multirow{4}{*}{0.730} \\
\hline & Overall, cruise traveling worth my time and effort. & 0.62 & \\
\hline & Overall, cruise traveling is much better than what I expected. & 0.58 & \\
\hline & $\begin{array}{l}\text { Overall, cruise traveling as a vacation option is much better than similar options (flight, } \\
\text { train, etc.). }\end{array}$ & 0.66 & \\
\hline \multirow{5}{*}{ INT } & I'll encourage friends/family to participate in cruise travel. & 0.65 & \multirow{5}{*}{0.736} \\
\hline & I want to participate in cruise travel within 12 months. & 0.56 & \\
\hline & I intend to cruise on special day in the future (e.g. birthday, anniversary, etc.). & 0.53 & \\
\hline & Cruise traveling is my first choice for traveling in the future. & 0.87 & \\
\hline & I will save time and money within 12 months for participating in cruise travel. & 0.58 & \\
\hline Threshold & & $>0.50$ & $>0.70$ \\
\hline
\end{tabular}


This study used second-order factor in cruise traveling motivation section, and reliability and validity tests have been applied for the second-order factor. As discussed in Chapter 3, composite reliabilities (CR), average variance extracted (AVE), maximum shared squared variance (MSV), average shared squared variance (ASV), and discriminant validity table reported below. According to previous studies, convergent validity exists when the average variance extracted (AVE), and discriminant validity occurs when measurement items from two or more different factors are not significantly correlated (Beckman, 2013b; Fornell \& Larcker, 1981). Hair et al. (2006) and Beckman (2013) mentioned that "discriminant validity includes whether MSV is less than the AVE and whether the ASV is less than the AVE", meaning that MSV and ASV for each construct need to be less than AVE for each construct in order to provide further confirmation of discriminant validity. $\operatorname{MaxR}(\mathrm{H})$ which refers to McDonald Construct Reliability is also estimated. $\operatorname{MaxR}(\mathrm{H})$ statistics are estimated to ensure the reliability of the six constructs. Table 17 presented validity and reliability table and Table 18 reported the discriminant validity of the final measurement model.

Table 17. Validity and Reliability of the Final Measurement Model

\begin{tabular}{|c|c|c|c|c|}
\hline Construct & CR & AVE & MSV & MaxR(H) \\
\hline ATT & 0.630 & 0.365 & 0.630 & 0.644 \\
\hline SN & 0.891 & 0.621 & 0.655 & 0.898 \\
\hline PBC & 0.831 & 0.496 & 0.341 & 0.833 \\
\hline TS & 0.730 & 0.404 & 0.994 & 0.734 \\
\hline INT & 0.736 & 0.360 & 0.994 & 0.743 \\
\hline Motivation & 0.706 & 0.399 & 0.655 & 0.770 \\
\hline Threshold & $>0.70$ & \multicolumn{2}{|c|}{ MSV < AVE } & \\
\hline
\end{tabular}

ATT=Attitude towards behavior; $\mathrm{SN}=$ Subjective Norm; $\mathrm{PBC}=$ Perceived behavioral control; TS=Travel satisfaction; INT=Behavioral intention; $\mathrm{CR}=$ Composite reliability; AVE=Average Variance Extracted; MSV=Maximum shared squared variance; $\operatorname{MaxR}(\mathrm{H})=$ Maximum reliability. 
Table 18. Discriminant Validity of the Final Measurement Model

\begin{tabular}{|c|c|c|c|c|c|c|}
\hline Construct & ATT & SN & PBC & TS & INT & Motivation \\
\hline ATT & 0.605 & & & & & \\
\hline SN & 0.224 & 0.788 & & & & \\
\hline PBC & 0.325 & 0.312 & 0.704 & & & \\
\hline TS & 0.794 & 0.273 & 0.524 & 0.636 & & \\
\hline INT & 0.671 & 0.396 & 0.584 & 0.997 & 0.600 & \\
\hline Motivation & 0.241 & 0.809 & 0.469 & 0.475 & 0.674 & 0.631 \\
\hline
\end{tabular}

ATT=Attitude towards behavior; $\mathrm{SN}=$ Subjective Norm; $\mathrm{PBC}=$ Perceived behavioral control; TS=Travel satisfaction; INT=Behavioral intention.

As the table showed, most of MSV values are greater than the AVEs, which means the general validity for this measurement model is not acceptable. This situation could be caused by three reasons, as follows: (1) The reliability of data sources is not high enough because of collecting data through online purely in China from the United States; (2) This is the first study to combine both Theory of Planned Behavior and Motivation Satisfaction Theory in cruise tourism research, and the validity of some constructs need to be reconsidered; and (3) Since there are more than 25 variables, 572 respondents are not enough to represent the whole population.

Validity is an integrated evaluative judgment of the degree to which empirical evidence and theoretical rationales support the adequacy and appropriateness of inferences and actions based on model fit (Messick, 1989). More broadly, scholars need to concern the validity at the beginning of SEM, not only the validity of all the measurement procedures used, but also the validity of the research design, the experimental methods, and conclusions and inferences (Drost, 2011). However, Kahle \& Malhotra (1994) argued that AVE is often too strict, and reliability can be established through CR alone.

For increasing the validity in the future, the researcher could collect data from consumers face to face near the ports in China or access the secondary database from cruise 
companies directly. Moreover, as the construct Travel Satisfaction is highly correlated with some factors in the Theory of Planned Behavior, the researcher needs to run more tests to check if the construct Travel Satisfaction could integrate with the Theory of Planned Behavior.

\section{Structural Equation Evaluation}

The research model included the proposed relationships among exogenous (independent variables) and endogenous (dependent variables) variables and was tested using a structural equation model (SEM). Independent variables in this study included firstorder motivational factors Self-esteem and self-recognition, Enjoy nature, Family togetherness, and Socialization and bonding; also, the planned behavior factors Subjective norm and Perceived behavioral control. Dependent variables included second-order factor Motivation, Attitude towards behavior, Behavioral intention, and Travel satisfaction.

Overall statistics for the structural model include: chi-square $(\mathrm{df})=1481.275(608)$; chi-square $/ \mathrm{df}=2.436 ; \mathrm{CFI}=0.916 ; \mathrm{SRMR}=0.075 ; \mathrm{RMSEA}=0.050 ;$ and $\mathrm{PClose}=0.472$. These fit statistics conclude that the data fit the proposed research model. Table 19 and Figure 9 presented the results of the proposed hypotheses. Indicators of the hypothesis support included standardized regression estimates, path weight significance, previous studies and theory. Standard errors, standardized regression weights, and critical ratios for each construct are provided in Table 19. 
Table 19. The Standardized Regression Weights for Hypotheses 1 through 9

\begin{tabular}{|c|l|c|c|c|c|c|}
\hline $\begin{array}{c}\text { Hypo } \\
\text { thesis }\end{array}$ & \multicolumn{1}{|c|}{ Structural Path } & $\begin{array}{c}\text { Standardized } \\
\text { Regression } \\
\text { Weight }\end{array}$ & $\begin{array}{c}\text { Standard } \\
\text { Error }\end{array}$ & $\begin{array}{c}\text { Critical } \\
\text { Ratio }\end{array}$ & $\begin{array}{c}\text { p- } \\
\text { value }\end{array}$ & Result \\
\hline H1 & $\begin{array}{l}\text { Attitude Towards Behavior } \rightarrow \text { Behavioral } \\
\text { Intention }\end{array}$ & 0.120 & 0.054 & 2.543 & $* *$ & Significant \\
\hline H2 & Subjective Norm $\rightarrow$ Behavioral Intention & 0.157 & 0.102 & 9.166 & $* * *$ & Significant \\
\hline H3 & $\begin{array}{l}\text { Perceived Behavioral Control } \rightarrow \text { Behavioral } \\
\text { Intention }\end{array}$ & 0.130 & 0.023 & 3.279 & $* * *$ & Significant \\
\hline H4 & Subjective Norm $\rightarrow$ Attitude Towards Behavior & 0.178 & 0.053 & 6.517 & $* * *$ & Significant \\
\hline H5 & $\begin{array}{l}\text { Perceived Behavioral Control } \rightarrow \text { Attitude Towards } \\
\text { Behavior }\end{array}$ & 0.191 & 0.031 & 6.517 & $* * *$ & Significant \\
\hline H6 & Motivation $\rightarrow$ Attitude Towards Behavior & 0.196 & 0.033 & 3.150 & $* * *$ & Significant \\
\hline H7 & Motivation $\rightarrow$ Satisfaction & 0.564 & 0.041 & 7.992 & $* * *$ & Significant \\
\hline H8 & Satisfaction $\rightarrow$ Behavioral Intention & 0.864 & 0.085 & 10.268 & $* * *$ & Significant \\
\hline H9 & Motivation $\rightarrow$ Behavioral Intention & 0.152 & 0.035 & 2.591 & $* *$ & Significant \\
\hline
\end{tabular}

$\mathrm{P}<0.05$ : significant. 


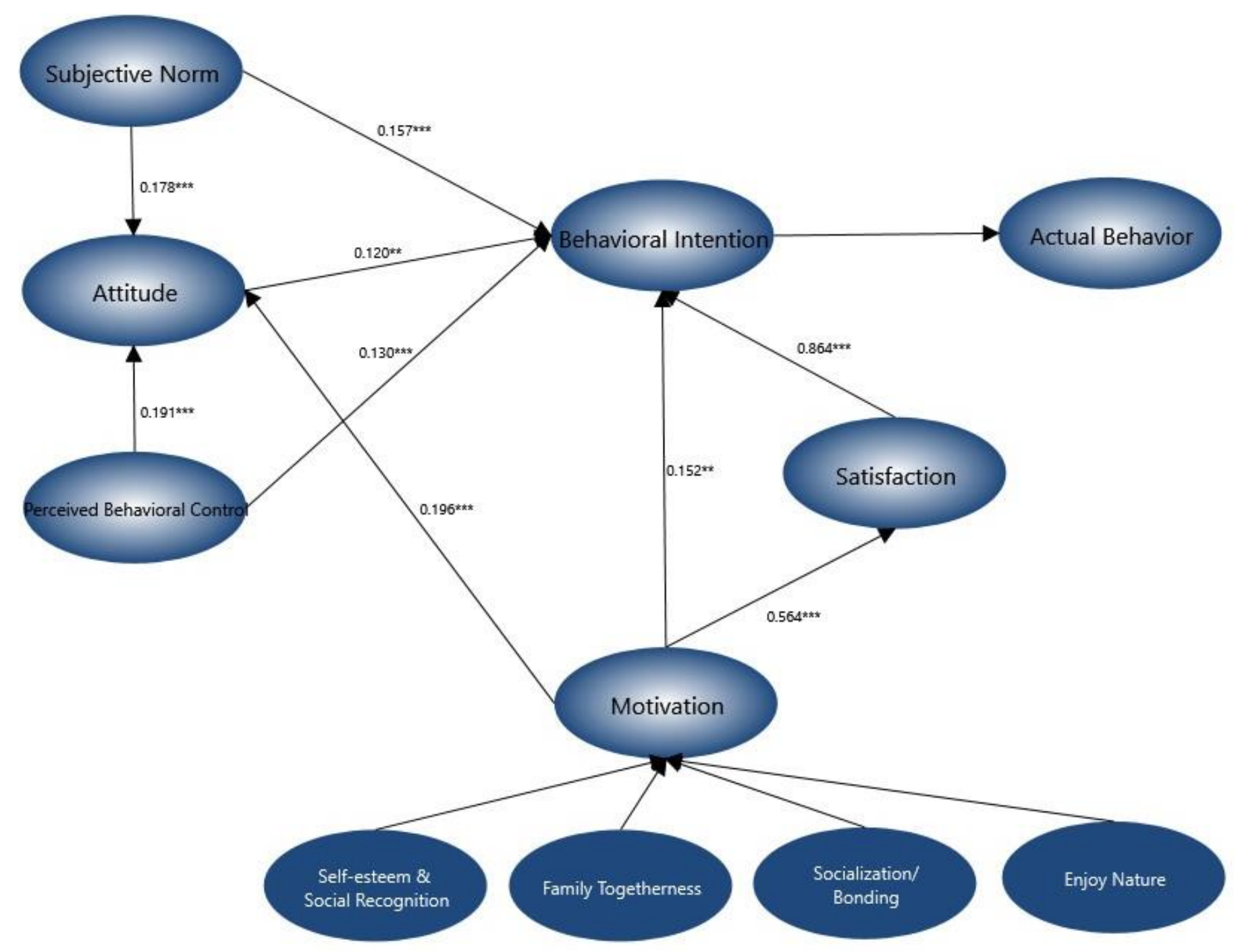

Figure 9. Proposed Research Model with Standardized Regression Weights 


\section{Hypotheses Testing}

H1. Chinese cruise travel attitudes exert a positive influence upon Chinese cruise travel intention.

The path weight of H1 (0.120) was significant at $\mathrm{p}<0.01$ level. Chinese cruise travel attitudes exert a positive influence on Chinese cruise travel intention. As a result, $\mathrm{H} 1$ was accepted. Thus, cruise tourists' intention is affected by how they think about cruise traveling. People who think cruise travel positively are more likely to participate in cruise traveling.

H2. Subjective norms have a positive effect on Chinese cruise travel intention.

The path weight of $\mathrm{H} 2(0.157)$ was significant at $\mathrm{p}<0.001$ level. Subjective norms have a positive effect on Chinese cruise travel intention. As a result, $\mathrm{H} 2$ was accepted. Therefore, cruise tourists' intention is affected by an individual's perceptions of what others think of participating in cruise traveling. People would pay attention to others' ideas about cruise travel before making a decision. If others have positive thinking of cruise travel, people will have more intention to participate in cruise traveling.

H3. Perceived behavior control positively influences Chinese cruise travel intention.

The path weight of H3 (0.130) was significant at $\mathrm{p}<0.001$ level. Perceived behavioral control positively influenced Chinese cruise travel intention. As a result, $\mathrm{H} 3$ was accepted. Thus, cruise tourists' intention is affected by an individual's perceptions of their abilities to perform a given behavior. If consumers believe they could have enough ability to participate in cruise traveling, the behavioral intention of cruise traveling would be stronger. 
H4. Subjective norms have a positive effect on Chinese cruise travel attitude.

The path weight of $\mathrm{H} 4(0.178)$ was significant at $\mathrm{p}<0.001$ level. Subjective norms have a positive effect on Chinese cruise travel attitude. As a result, H4 was accepted. Therefore, Chinese cruise travelers' attitudes are influenced by what others think of when participating in cruise traveling, which means if others highly recommend cruise traveling in China, people would think of cruise traveling positively.

H5. Perceived behavior control positively influences Chinese cruise travel attitude.

The path weight of H5 (0.191) was significant at $\mathrm{p}<0.001$ level. Perceived behavior control positively influenced Chinese cruise travel attitude. As a result, H5 was accepted. Thus, cruise tourists' attitudes to participate in cruise traveling are affected by an individual's perceptions of their abilities to perform a given behavior. It means when people have enough ability, such as time, money and opportunity to travel with cruise lines, they would have better attitudes about cruise traveling.

H6. Chinese cruise travel motivation has a positive effect on Chinese cruise travel attitude.

The path weight of H6 (0.196) was significant at $\mathrm{p}<0.001$ level. Chinese cruise travel motivation has a positive effect on Chinese cruise travel attitude. As a result, H6 was accepted. Therefore, cruise tourists' attitudes to participate in cruise traveling are affected by their motivations, which means if Chinese consumers have stronger motivation to participate in cruise traveling, they would have better ideas about cruise traveling.

H7. Chinese cruise travel motivation has a positive effect on Chinese cruise travel satisfaction.

The path weight of $\mathrm{H} 7$ (0.564) was significant at $\mathrm{p}<0.001$ level. Chinese cruise travel motivation has a positive effect on Chinese cruise travel satisfaction. As a result, $\mathrm{H} 7$ 
was accepted. Therefore, cruise tourists' satisfaction is affected by cruise travel motivation, such as self-esteem and social recognition, family togetherness, socialization and bonding, and nature scenery. If the Chinese consumer is strongly motivated before participating in cruise traveling, they will be more satisfied when they travel with cruise lines.

H8. Chinese cruise travel satisfaction positively influences Chinese cruise travel intention.

The path weight of H8 (0.864) was significant at $\mathrm{p}<0.001$ level. Chinese cruise travel satisfaction positively influenced Chinese cruise travel intention. As a result, H8 was accepted. Therefore, cruise travel intention in China is affected by consumer satisfaction from the past cruise travel experience. People who are satisfied with past cruise travel experience would consider cruising as a vacation more in China.

H9. Chinese cruise travel motivation positively directly affects Chinese cruise travel intention.

The path weight of H9 (0.152) was significant at $\mathrm{p}<0.01$ level. Chinese cruise travel motivation positively directly affected Chinese cruise travel intention. As a result, H9 was accepted. Thus, cruise tourists' intention is directly affected by cruise travel motivation, which means several factors could influence consumers' perceptions and decisions of participating in cruise traveling. Each consumer has its own needs and demands, and those needs and demands would bring direct effects on cruise travel intention. 


\section{CHAPTER 5: DISCUSSION}

\section{Discussion 1. What do Chinese people prefer when cruising?}

As discussed in Chapter 4, respondents prefer traveling via cruise to Japan (66.1\%), Europe $(62.1 \%)$, and Southeast Asia (58.5\%) the most. Surprisingly, less than $50 \%$ of respondents prefer participating in cruise traveling to Korea which was the most attractive cruise destination in the past. A variety of travel-planning time horizons were reported, with 1 to 2 months $(50.4 \%)$ in advance being the most popular. Online travel agency (70.7\%) is the most likely channel for booking a cruise, followed by cruise company (20.8\%). Compared to the results of previous studies, the favorite cruise booking channel has changed to online travel agencies and cruise companies from traditional travel agencies (Fan \& Hsu, 2014). As for cruise duration, 7 to 9 days (44.2\%) was the most preferred option, followed by 4 to 6 days $(33.0 \%)$ and 10 to 15 days (16.4\%).

In conclusion, Chinese people prefer Japan, Europe, and Southeast Asia as cruise traveling destination with 7 to 9 days duration. Furthermore, cruise tourists prefer to plan and book cruise products 1 to 2 months in advance from online travel agency.

\section{Discussion 2. What drives Chinese consumers to participate in cruise travel?}

From the results of hypotheses testing, attitude towards Chinese cruise traveling positively affects consumer future behavioral intention of traveling with cruise lines, which showed that the majority of people in China have accepted cruise in their life, and attitude towards cruise traveling is affecting Chinese consumers cruise traveling. Motivational items, such as self-esteem and social recognition, family togetherness, socialization and bonding, and nature scenery, are highly affecting cruise tourists' travel satisfaction. Each 
individual has its own needs and demands, which means motivational items could be different from person to person. Furthermore, Chinese cruise travelers' satisfaction is highly correlated to cruise tourists' behavioral intention, and cruise travelers' motivation directly impacted cruise tourists' behavioral intention. Thus, Chinese consumers could be driven by variable motivational items and satisfaction from past cruise traveling experience. Moreover, the path of subjective norm and perceived behavioral control to behavioral intention has been prove significant, indicating that subjective norm and perceived behavioral control could have impact on intention to travel with cruise.

In conclusion, attitude towards cruise traveling, subjective norm, perceived behavioral control, motivational items, and travel satisfaction from past cruise traveling experiences could drives Chinese consumers to participate in cruise travel.

\section{Discussion 3. How might cruise companies attract more consumers in China?}

This study examined the cruise travel motivation and traveling intentions in China, and its results can be utilized by cruise companies and travel agencies to meet Chinese cruise travelers' needs and maximize their profits. As concluded in Discussion 2, attitude towards cruise traveling, subjective norms, perceived behavioral control, motivational items, and travel satisfaction could impact Chinese travelers consumption of cruise products. Cruise companies could deploy their strategies based on each factor in the model.

Attitude Towards Behavior (ATT). Knowing what consumers care about is important for cruise companies. According to the previous studies, cruise tourists were

more concerned about the branding and the reputation of the cruise company, indicating that companies could build up brand recognition and reputation to attract consumers. 
Furthermore, as the cruise culture in China is still developing, cruise companies could hold more events to increase the cruise culture's acceptance in China.

Subjective Norm (SN). People will always care about what others think about cruise traveling in China, and if others believe cruise traveling is good and worthy, people would intend to travel with cruise more. Cruise companies could promote their products through word-of-mouth. Word-of-mouth marketing is a powerful asset in the line of work, and it not only piques people's interest, but also the same time, gets people talking. About $62 \%$ of consumers search online for reviews and information before purchasing a cruise product and a $90 \%$ believe brand recommendations from friends. Cruise companies need to offer a unique and shareworthy experience to consumers and encourage consumers to provide feedback after traveling with cruise. Moreover, creating a referral program could enhance the reputation of the cruise life through word-of-mouth for marketing in China.

Perceived Behavioral Control (PBC). China's economy is growing rapidly, and more and more people have enough money to consume cruise products. However, cruise companies and travel agencies are using the Chartered Distribution Model to sell products, which currently causes virulent price competition in the cruise industry. This competition confuses some cruise travelers, and the distribution strategy needs to be revolutionized. Cruise companies could increase direct distribution in China, and pricing strategy and pricing authority should be controlled by the companies. Furthermore, respondents' favorite cruise traveling duration is 7 to 9 days, and cruise companies in China could forms this duration in their marketing.

Motivation. As discussed above, cruise motivation could be different from person to person. For attracting different consumers, cruise companies could promote personalized 
products, and consumers could have diverse cruise products in China. Customizing meals, drinks, activities and children's entertainments on cruise ships could satisfy different consumers' needs and demands.

Travel Satisfaction (TS). Travel satisfaction showed high correlation to behavioral intention, and cruise companies could focus on enhancing travelers' travel satisfaction. For increasing travel satisfaction, cruise companies need to understand the needs and demands of cruise travelers. Moreover, solving complaint issues on time is necessary.

Behavioral Intention (INT). Most of people strongly agree with "I intend to cruise on special day in the future (e.g. birthday, anniversary, etc.)" in the survey, indicating that there is a high intention to cruise on a special day, and cruise companies could consider developing diverse cruise products. There are plenty of traditional holidays in China, and cruise companies can set up celebration events on board to engage consumers' needs. 


\section{CHAPTER 6: IMPLICATIONS}

\section{Theoretical Implications}

From a theoretical perspective, this research offered two important contributions.

First of all, it supported the findings of past empirical studies (Fan \& Hsu, 2014; Fan et al., 2015; Fu et al., 2010; Han \& Hyun, 2018; Hung \& Petrick, 2010, 2011; Xie et al., 2012) that attitudes, travel satisfaction, and cruise motivation have vial roles in the formation of behavioral intention. Secondly, it extended the existing knowledge on behavioral intention formation, especially the motivational items and travel satisfaction construct are also important determinants of behavioral intention. Conceptually, this study offers empirical evidence that the Theory of Planned Behavioral and Motivation - Satisfaction Theory makes up the essential structure of the formation of behavioral intention in the cruise tourism industry. Future studies, especially in cruise tourism, should incorporate motivation and travel satisfaction as behavioral intention drivers. This is the first combination of the Theory of Planned Behavior and Motivation - Satisfaction Theory as previous studies have not addressed the effect of both motivation and travel satisfaction constructs in a comprehensive behavioral intention model, especially in the cruise industry. Therefore, future studies in the cruise industry that aim to examine the model of behavioral intention should include not only subjective norm, attitude towards behavior, and perceived behavioral control, but also motivation and travel satisfaction constructs.

\section{Managerial Implications}

The major findings of this study have significant managerial implications for cruise tourism business in China. This study examined cruise travel motivation and traveling 
intentions in China, and its results can be utilized by cruise companies and travel agencies to meet Chinese cruise travelers' needs and maximize their profits. According to the findings in this study, cruise companies could deploy their strategies based on each factor in the model, including subjective norm, attitude towards cruise traveling behavior, perceived behavioral control, cruise travel motivation, cruise travel satisfaction, and cruise travel intention. Most of these managerial implications have been discussed in Chapter 5 .

\section{Limitation and Future Research}

This study, however, has its own limitations: First of all, the survey was conducted to 573 people, and it is not enough to give an in — depth evaluation of such a comprehensive model. Future research may collect more data to accomplish the model requirements. Secondly, although model fit is excellent, the validity is not acceptable generally because of data collection, reliability of data, and the combination of both theories. Future study may consider and check validity from data collection and theory selection. Thirdly, this is

the first attempt to integrate the Theory of Planned Behavior and Motivation - Satisfaction Theory in the cruise industry, and it only included 4 motivational factors. Future research may test more motivational factors and travel satisfactions items. However, this study found interesting findings which can inspire more in-depth future research to get more accurate results and high-quality information. 


\section{REFERENCES}

Agyeiwaah, E., Otoo, F. E., Suntikul, W., \& Huang, W. J. (2019). Understanding culinary tourist motivation, experience, satisfaction, and loyalty using a structural approach. Journal of Travel and Tourism Marketing. https://doi.org/10.1080/10548408.2018.1541775

Agyekum, C. K., Haifeng, H., Agyeiwaa, A., Agyekum, C. K., Haifeng, H., \& Agyeiwaa, A. (2015). Consumer Perception of Product Quality. Microeconomics and Macroeconomics. https://doi.org/10.5923/j.m2economics.20150302.01

Ajzen, I. (1991). The theory of planned behavior. Organizational Behavior and Human Decision Processes. https://doi.org/10.1016/0749-5978(91)90020-T

Ajzen, I. (2009). Theory of Planned Behavior Measure. Change. Journal of Health Psychology, 12(1), 1-8. https://doi.org/10.1037/t15668-000

Ajzen, I. (2013). Theory of Planned Behaviour Questionnaire. Measurement Instrument Database for the Social Science. https://doi.org/http://dx.doi.org/10.13072/midss.649

Andriotis, K., \& Agiomirgianakis, G. (2010). Cruise visitors' experience in a mediterranean port of call. International Journal of Tourism Research. https://doi.org/10.1002/jtr.770

Armitage, J. C., \& Conner, M. (2001). Efficacy of the Theory of Planned Behaviour: A meta-analytic review. British Journal of Social Psychology, 40, 471-499.

Association Cruise Line International. (2018). 2018 Asia Cruise Trends. Clia. Retrieved from https://cruising.org/news-and-research/research/2018/december/asia-trends2018-overview

Bagozzi, R. P., \& Yi, Y. (1988). On the evaluation of structural equation models. Journal of the Academy of Marketing Science. https://doi.org/10.1007/BF02723327

Bamberg, S., Ajzen, I., \& Schmidt, P. (2003). Choice of Travel Mode in the Theory of Planned Behavior: The Roles of Past Behavior, Habit, and Reasoned Action. Basic and Applied Social Psychology. https://doi.org/10.1207/S15324834BASP2503_01

Beckman, E. (2013a). The Impact of Motivations and Enduring Involvement in an Adventure Tourism Setting (University of Tennessee). Retrieved from https://trace.tennessee.edu/utk_graddiss/2398 
Beckman, E. (2013b). The Impact of Motivations and Enduring Involvement in an Adventure Tourism Setting. University of Tennessee.

Bentler, P. M. (1990). Comparative fit indexes in structural models. Psychological Bulletin. https://doi.org/10.1037/0033-2909.107.2.238

Bentler, P. M., \& Bonett, D. G. (1980). Significance tests and goodness of fit in the analysis of covariance structures. Psychological Bulletin. https://doi.org/10.1037/0033-2909.88.3.588

Blatná, D. (2014). Application of Robust Regression and Bootstrap in Productivity Analysis of GERD Variable in EU27. Statistika: Statistics and Economy Journal, Vol. 94(2), 62-76.

Bollen, K. A. (1989). A New Incremental Fit Index for General Structural Equation Models. Sociological Methods \& Research. https://doi.org/10.1177/0049124189017003004

Brislin, R. W. (1976). Comparative research methodology: Cross-cultural studies. International Journal of Psychology. https://doi.org/10.1080/00207597608247359

Brown, T. a. (2006). Confirmatory Factor Analysis for Applied Researchers. In Methodology in the Social Sciences.

Browne, M. W. (1984). Asymptotically distribution-free methods for the analysis of covariance structures. British Journal of Mathematical and Statistical Psychology. https://doi.org/10.1111/j.2044-8317.1984.tb00789.x

Browne, Michael W., \& Cudeck, R. (1992). Alternative Ways of Assessing Model Fit. Sociological Methods \& Research. https://doi.org/10.1177/0049124192021002005

Byrne, M. E. (2006). Shoot meristem function and leaf polarity: The role of class III HDZIP genes. PLoS Genetics. https://doi.org/10.1371/journal.pgen.0020089

Byrne, R. W. (2009). The Technical Intelligence hypothesis: An additional evolutionary stimulus to intelligence? In Machiavellian Intelligence II.

https://doi.org/10.1017/cbo9780511525636.012

Cangur, S., \& Ercan, I. (2015). Comparison of model fit indices used in structural equation modeling under multivariate normality. Journal of Modern Applied Statistical Methods. https://doi.org/10.22237/jmasm/1430453580

Cha, S., McCleary, K. W., \& Uysal, M. (1995). Travel motivations of Japanese overseas travelers: a factor-cluster segmentation approach. Journal of Travel Research. https://doi.org/10.1177/004728759503400104 
Chan, C. S., Yuen, S. K., Duan, X., \& Marafa, L. M. (2018). An analysis of push-pull motivations of visitors to Country Parks in Hong Kong. World Leisure Journal. https://doi.org/10.1080/16078055.2018.1496527

Chang, J. C. (2008). Tourists' Satisfaction Judgments: An Investigation of Emotion, Equity, and Attribution. Journal of Hospitality and Tourism Research. https://doi.org/10.1177/1096348007309571

Chen, Z. (南华大学). (2016). Applying the theory of planned behavior to explore tourists' behavioral intention toward cruise tour. Nanhua University.

Cheung, L. T. O. (2013). Improving visitor management approaches for the changing preferences and behaviours of country park visitors in Hong Kong. Natural Resources Forum. https://doi.org/10.1111/1477-8947.12025

Chien, G. C. L., Yen, I. Y., \& Hoang, P. Q. (2012). Combination of Theory of Planned Behavior and Motivation: An Exploratory Study of Potential Beach-based Resorts in Vietnam. Asia Pacific Journal of Tourism Research, 17(5), 489-508. https://doi.org/10.1080/10941665.2011.627352

Chul Oh, H., Uysal, M., \& Weaver, P. A. (1995). Product bundles and market segments based on travel motivations: a canonical correlation approach. International Journal of Hospitality Management. https://doi.org/10.1016/0278-4319(95)00010-A

Churchill, G. A. (1979). A Paradigm for Developing Better Measures of Marketing Constructs. Journal of Marketing Research. https://doi.org/10.2307/3150876

Creswell, J. W. (2012). Educational research: Planning, conducting, and evaluating quantitative and qualitative research. In Educational Research. https://doi.org/10.1017/CBO9781107415324.004

Crompton, J. L. (1979). Motivations for pleasure vacation. Annals of Tourism Research. https://doi.org/10.1016/0160-7383(79)90004-5

Crompton, J. L., \& McKay, S. L. (1997). Motives of visitors attending festival events. Annals of Tourism Research.

Cronbach, L. J., \& Shavelson, R. J. (2004). My Current Thoughts on Coefficient Alpha and Successor Procedures. Educational and Psychological Measurement. https://doi.org/10.1177/0013164404266386

Dann, G. M. S. (1981). Tourist motivation an appraisal. Annals of Tourism Research. https://doi.org/10.1016/0160-7383(81)90082-7 
Dean, D., \& Suhartanto, D. (2019). The formation of visitor behavioral intention to creative tourism: the role of push-Pull motivation. Asia Pacific Journal of Tourism Research. https://doi.org/10.1080/10941665.2019.1572631

Decarlo, L. T. (1997). Psychological Methods Copyright 1997 by the American Psychological Association. Psychological Methods.

Devesa, M., Laguna, M., \& Palacios, A. (2010). The role of motivation in visitor satisfaction: Empirical evidence in rural tourism. Tourism Management. https://doi.org/10.1016/j.tourman.2009.06.006

Drost, E. A. (2011). Validity and Reliability in Social Science Research. Education Research and Perspectives.

Duman, T., \& Mattila, A. S. (2005). The role of affective factors on perceived cruise vacation value. Tourism Management. https://doi.org/10.1016/j.tourman.2003.11.014

Dunn Ross, E. L., \& Iso-Ahola, S. E. (1991). Sightseeing tourists' motivation and satisfaction. Annals of Tourism Research. https://doi.org/10.1016/01607383(91)90006-W

Dwyer, L., \& Forsyth, P. (1998). Economic significance of cruise tourism. Annals of Tourism Research, 25(2), 393-415. https://doi.org/10.1016/S0160-7383(97)00098-4

Fan, D. X. F., \& Hsu, C. H. C. (2014). Potential Mainland Chinese Cruise Travelers' Expectations, Motivations, and Intentions. Journal of Travel and Tourism Marketing. https://doi.org/10.1080/10548408.2014.883948

Fan, D. X. F., Qiu, H., Hsu, C. H. C., \& Liu, Z. G. (2015). Comparing Motivations and Intentions of Potential Cruise Passengers from Different Demographic Groups: The Case of China. Journal of China Tourism Research, 11(4), 461-480. https://doi.org/10.1080/19388160.2015.1108888

Figler, M. H., Weinstein, A. R., Sollers, J. J., \& Devan, B. D. (1992). Pleasure travel (tourist) motivation: A factor analytic approach. Bulletin of the Psychonomic Society. https://doi.org/10.3758/BF03330412

Fornell, C., \& Larcker, D. F. (1981). Evaluating Structural Equation Models with Unobservable Variables and Measurement Error. Journal of Marketing Research. https://doi.org/10.2307/3151312

Fu, X., Huang, J., \& Cai, L. (2010). Chinese cruise tourists' motivations: a culturalhistorical perspective. 29th Annual Conference of International Society of Travel and Tourism Educators, 18-22 October. 
Hair, J. F., Black, W. C., Babin, B. J., \& Anderson, R. E. (2006). Multivariate Data Analysis (6th ed.). Analysis.

Han, H., \& Hyun, S. S. (2018). Role of motivations for luxury cruise traveling, satisfaction, and involvement in building traveler loyalty. International Journal of Hospitality Management, 70(November 2017), 75-84. https://doi.org/10.1016/j.ijhm.2017.10.024

Han, H., \& Hyun, S. S. (2019). Cruise travel motivations and repeat cruising behaviour: impact of relationship investment. Current Issues in Tourism. https://doi.org/10.1080/13683500.2017.1313204

Harvey, D. (1989). The Condition To Postmodernity (Vol. 14) (D. Harvey, Ed.). Oxford: Blackwell.

Hobson, J. S. P., \& Josiam, B. (1996). Spring break student travel: A longitudinal study. Journal of Vacation Marketing. https://doi.org/10.1177/135676679600200204

Hsu, C. H. C., \& Huang, S. (2012). An Extension of the Theory of Planned Behavior Model for Tourists. Journal of Hospitality and Tourism Research, 36(3), 390-417. https://doi.org/10.1177/1096348010390817

Huang, J. H., Lin, Y. R., \& Chuang, S. T. (2007). Elucidating user behavior of mobile learning: A perspective of the extended technology acceptance model. Electronic Library. https://doi.org/10.1108/02640470710829569

Hung, K., \& Petrick, J. F. (2010). Developing a Measurement Scale for Constraints To Cruising. Annals of Tourism Research, 37(1), 206-228. https://doi.org/10.1016/j.annals.2009.09.002

Hung, K., \& Petrick, J. F. (2011). Why do you cruise? Exploring the motivations for taking cruise holidays, and the construction of a cruising motivation scale. Tourism Management. https://doi.org/10.1016/j.tourman.2010.03.008

Hyun, S. S., \& Han, H. (2015). Luxury Cruise Travelers: Other Customer Perceptions. Journal of Travel Research. https://doi.org/10.1177/0047287513513165

International, R. C. (2013). The Chinese cruise market profile study. 8th China Cruise Shipping \& International Cruise Expo. Retrieved from https://www.royalcaribbean.com/china-cruises

Jim, C. Y. (1989). Changing patterns of country-park recreation in Hong Kong. Geograhical Journal. https://doi.org/10.2307/635058

Johnson, D. (2002). Environmentally sustainable cruise tourism: A reality check. Marine Policy. https://doi.org/10.1016/S0308-597X(02)00008-8 
Jöreskog, K. G. (1967). Some contributions to maximum likelihood factor analysis. Psychometrika. https://doi.org/10.1007/BF02289658

Joreskog, K. G., \& Sorbom, D. (1982). Recent Developments in Structural Equation Modeling. Journal of Marketing Research. https://doi.org/10.2307/3151714

Joreskog, K., \& Sorbom, D. (1993). LISREL 8 user's reference guide. Scientific Software International.

Josiam, B. M., Huang, T. Y., Spears, D. L., Kennon, L., \& Bahulkar, G. A. (2009). Understanding ethnic chinese travelers on north american cruise tours: Motivations, Perceptions, and satisfaction of cruisers. Journal of China Tourism Research, 5(1), 77-101. https://doi.org/10.1080/19388160802711428

Jung, H.-K., \& Han, H.-S. (2016). Loyalty Intention Formation for Cruise Travel: The Moderating Impact of Perceived Risk and the Mediating Impact of Affective Experience. Journal of Tourism Sciences. https://doi.org/10.17086/jts.2016.40.4.181.196

Kah, J. A., \& Lee, S. H. (2016). A new approach to travel information sources and travel behaviour based on cognitive dissonance theory. Current Issues in Tourism, 19(4), 373-393. https://doi.org/10.1080/13683500.2015.1043246

Kahle, L. R., \& Malhotra, N. K. (1994). Marketing Research: An Applied Orientation. Journal of Marketing Research. https://doi.org/10.2307/3151953

Kim, K. (2008). Analysis of structural equation model for the student pleasure travel market: Motivation, involvement, satisfaction, and destination loyalty. Journal of Travel and Tourism Marketing. https://doi.org/10.1080/10548400802156802

Kim, S., Kim, I., \& Hyun, S. S. (2016). First-Class in-Flight Services and Advertising Effectiveness: Antecedents of Customer-Centric Innovativeness and Brand Loyalty in the United States (US) Airline Industry. Journal of Travel and Tourism Marketing. https://doi.org/10.1080/10548408.2015.1038420

Kim, S. S., Lee, C. K., \& Klenosky, D. B. (2003). The influence of push and pull factors at Korean national parks. Tourism Management. https://doi.org/10.1016/S02615177(02)00059-6

Kotler, P. (2000). Marketing Management, Millenium Edition. Marketing Management. https://doi.org/10.1016/0024-6301(90)90145-T

Lam, T., \& Hsu, C. H. C. (2006). Predicting behavioral intention of choosing a travel destination. Tourism Management, 27(4), 589-599. https://doi.org/10.1016/j.tourman.2005.02.003 
Lee, S., \& Ramdeen, C. (2013). Cruise ship itineraries and occupancy rates. Tourism Management. https://doi.org/10.1016/j.tourman.2012.03.009

Liu, D. (2019). Predicting Tourists' Revisiting Behavioral Intention in Wind Energy Tourism Context: An Integrative Model of the Theory of Planned Behavior and Value-Belief-Norm Theory (City University of Macau). https://doi.org/10.1017/CBO9781107415324.004

Lyu, J., Hu, L., Hung, K., \& Mao, Z. (2017). Assessing servicescape of cruise tourism: the perception of Chinese tourists. International Journal of Contemporary Hospitality Management. https://doi.org/10.1108/IJCHM-04-2016-0216

Manfredo, M. J., Driver, B. L., \& Tarrant, M. A. (1996). Measuring leisure motivation: A meta-analysis of the Recreation Experience Preference scales. Journal of Leisure Research.

Mayo, E.J., \& Jarvis, L. . (1981). The Psychology of Leisure Travel: Effective Marketing and Selling of Travel Services. In Cbi Publishing Co: Boston.

Mayo, E. (1975). Tourism and the National Parks: A Psychographic and Attitudinal Study. Journal of Travel Research. https://doi.org/10.1177/004728757501400103

Messick, S. (1989). Meaning and Values in Test Validation: The Science and Ethics of Assessment. Educational Researcher. https://doi.org/10.3102/0013189X018002005

Mohammad, B. A. M. A.-H., \& Som, A. P. M. (2010). An Analysis of Push and Pull Travel Motivations of Foreign Tourists to Jordan. International Journal of Business and Management, 5(12), 41-50. Retrieved from www.ccsenet.org/ijbm

Mondou, V., \& Taunay, B. (2012). The adaptation strategies of the cruise lines to the Chinese tourists. Tourism.

Nyíri, P. (2008). Between encouragement and control: Tourism, modernity and discipline in China. In Asia on Tour: Exploring the Rise of Asian Tourism. https://doi.org/10.4324/9780203891803

Oliver, R. L., \& Swan, J. E. (1989). Consumer Perceptions of Interpersonal Equity and Satisfaction in Transactions: A Field Survey Approach. Journal of Marketing. https://doi.org/10.2307/1251411

Park, S. H., Hsieh, C. M., \& Lee, C. K. (2017). Examining Chinese College Students' Intention to Travel to Japan Using the Extended Theory of Planned Behavior: Testing Destination Image and the Mediating Role of Travel Constraints. Journal of Travel and Tourism Marketing, 34(1), 113-131. https://doi.org/10.1080/10548408.2016.1141154 
Pearce, P. L. (1982). Perceived changes in holiday destinations. Annals of Tourism Research. https://doi.org/10.1016/0160-7383(82)90044-5

Pearce, P. L. (2011). Destination Culture. Tourism, Museums and Heritage. Festival Management and Event Tourism. https://doi.org/10.3727/106527098791784448

Qu, H., \& Ping, E. W. Y. (1999). A service performance model of Hong Kong cruise travelers' motivation factors and satisfaction. Tourism Management. https://doi.org/10.1016/S0261-5177(98)00073-9

Reisinger, Y., \& Mavondo, F. (2006). Structural equation modeling critical issues and new developments. Journal of Travel and Tourism Marketing. https://doi.org/10.1300/J073v21n04_05

Reisinger, Y., \& Turner, L. (1999). Structural equation modeling with Lisrel: Application in tourism. Tourism Management. https://doi.org/10.1016/S0261-5177(98)00104-6

Research Centre for Coastal Tourism. (2012). Cruise Tourism: From a broad perspective to a focus on Zeeland. 4, 40.

Sampson, H. (2018). Norwegian Cruise Line is Moving Its Build-for-China Ship to the U.S. Retrieved from Skift website: https://skift.com/2018/07/18/norwegian-cruiseline-is-moving-its-built-for-china-ship-to-the-u-s/

Schneider, I., \& Sönmez, S. (1999). Exploring the touristic image of Jordan. Tourism Management. https://doi.org/10.1016/S0261-5177(99)00023-0

Schumm, W. R., \& Stevens, J. (1993). Applied Multivariate Statistics for the Social Sciences. The American Statistician. https://doi.org/10.2307/2685203

Seheult, A. H., Green, P. J., Rousseeuw, P. J., \& Leroy, A. M. (1989). Robust Regression and Outlier Detection. Journal of the Royal Statistical Society. Series A (Statistics in Society). https://doi.org/10.2307/2982847

Spearman, C. (1987). The Proof and Measurement of Association between Two Things. The American Journal of Psychology. https://doi.org/10.2307/1422689

Stec, C. (2019). Customer Perception: What It Is, Why It's Important, and How to Improve It. Retrieved from Hubspot website: https://blog.hubspot.com/service/improve-customer-perception

Sun, X., Feng, X., \& Gauri, D. K. (2014). The cruise industry in China: Efforts, progress and challenges. International Journal of Hospitality Management. https://doi.org/10.1016/j.ijhm.2014.05.009 
Tabachnick, B. G., \& Fidell, L. S. (2007). Chapter 13. Principal Components and Factor Analysis. In Using Multivariate Statistics, fifth edition.

Tabri, N., \& Elliott, C. M. (2012). Principles and Practice of Structural Equation Modeling. Canadian Graduate Journal of Sociology and Criminology. https://doi.org/10.15353/cgjsc-rcessc.v1i1.25

Teye, V. B., \& Leclerc, D. (1998). Product and service delivery satisfaction among North American cruise passengers. Tourism Management. https://doi.org/10.1016/S02615177(97)00107-6

Trochim, W. M. K. (2010). Time in research. Research Methods Knowledge Base. Web Center for Social Research Methods.

Tsai, L. M., \& Sakulsinlapakorn, K. (2016). Exploring Tourists' Push and Pull Travel Motivations to Participate in Songkran Festival in Thailand as a Tourist Destination: A Case of Taiwanese Visitors. J. of Tourism and Hospitality Management. https://doi.org/10.17265/2328-2169/2016.10.001

Tucker, L. R. (1955). The objective definition of simple structure in linear factor analysis. Psychometrika. https://doi.org/10.1007/BF02289018

Uysal, M., \& Jurowski, C. (1994). Testing the push and pull factors. Annals of Tourism Research. https://doi.org/10.1016/0160-7383(94)90091-4

Wang, J., \& Wang, X. (2012). Structural Equation Modeling: Applications Using Mplus. In Structural Equation Modeling: Applications Using Mplus. https://doi.org/10.1002/9781118356258

Weeden, C., Lester, J. A., \& Thyne, M. (2011). Cruise tourism: Emerging issues and implications for a maturing industry. Journal of Hospitality and Tourism Management. https://doi.org/10.1375/jhtm.18.1.26

Wheaton, B. (1987). Assessment of Fit in Overidentified Models with Latent Variables. Sociological Methods \& Research. https://doi.org/10.1177/0049124187016001005

Wong, B. K. M., Musa, G., \& Taha, A. Z. (2017). Malaysia my second home: The influence of push and pull motivations on satisfaction. Tourism Management. https://doi.org/10.1016/j.tourman.2017.03.003

Wood, P. (2008). Confirmatory Factor Analysis for Applied Research. The American Statistician. https://doi.org/10.1198/tas.2008.s98

Wood, R. E. (2000). Caribbean cruise tourism: Globalization at sea. Annals of Tourism Research, 27(2), 345-370. https://doi.org/10.1016/S0160-7383(99)00073-0 
Xie, H. J., Kerstetter, D. L., \& Mattila, A. S. (2012). The attributes of a cruise ship that influence the decision making of cruisers and potential cruisers. International Journal of Hospitality Management. https://doi.org/10.1016/j.ijhm.2011.03.007

Yang, Y. (2015). What Chinese cruisers want: An analysis of product preferences. Purdue University.

Yoon, Y., \& Uysal, M. (2005). An examination of the effects of motivation and satisfaction on destination loyalty: A structural model. Tourism Management, 26(1), 45-56. https://doi.org/10.1016/j.tourman.2003.08.016

Yuan, K. H., \& Zhong, X. (2013). Robustness of fit indices to outliers and leverage observations in structural equation modeling. Psychological Methods. https://doi.org/10.1037/a0031604

Yuzhanin, S., \& Fisher, D. (2016). The efficacy of the theory of planned behavior for predicting intentions to choose a travel destination: a review. Tourism Review, 71(2), 135-147. https://doi.org/10.1108/TR-11-2015-0055

Zhao, J. (Florida I. U. (2018). The Development and Change of the Cruise Industry in China over the Decade (2006-2016). In J. (Florida I. U. Zhao (Ed.), The Hospitality and Tourism Industry in China. Apple Academic Press (AAP) \& CRC Press (Taylor \& Francis Group). 
APPENDICES 


\section{Chinese Cruise Travelling Perception Research}

Dear Friends,

Thank you for participating in this survey studying perception of preferred needs and demands for Chinese cruise travelers. It will take a few minutes for you to complete the questionnaire. The information you provide will help governmental agencies, tourism business planners, cruise companies, travel agencies and university for the development of cruise business in China. I value your thoughts and opinions; the data collected from you will only be used for research purpose, and the information will be kept confidential.

Part 1 - Attitude Towards the Behavior (ATT) [Ref: Fishbein \& Ajzen, 1975; Park et al., 2017; Liu, 2019]

\begin{tabular}{|l|l|c|c|c|c|c|c|c|}
\hline \multicolumn{2}{|l|}{} & $\begin{array}{c}\text { Strongly } \\
\text { Disagree }\end{array}$ & & & Neutral & & \multicolumn{2}{|c|}{$\begin{array}{c}\text { Strongly } \\
\text { agree }\end{array}$} \\
\hline Q1 & For me, cruising is pleasant. & 1 & 2 & 3 & 4 & 5 & 6 & 7 \\
\hline Q2 & For me, cruising is fun. & 1 & 2 & 3 & 4 & 5 & 6 & 7 \\
\hline Q3 & For me, cruising is enjoyable. & 1 & 2 & 3 & 4 & 5 & 6 & 7 \\
\hline Q4 & For me, cruising is valuable. & 1 & 2 & 3 & 4 & 5 & 6 & 7 \\
\hline Q5 & For me, cruising is interesting. & 1 & 2 & 3 & 4 & 5 & 6 & 7 \\
\hline Q6 & For me, cruising is safe. & 1 & 2 & 3 & 4 & 5 & 6 & 7 \\
\hline
\end{tabular}

Part 2 - Subjective Norm (SN) [Ref: Park et al., 2017; Liu, 2019; Lam \& Hsu, 2006]

\begin{tabular}{|c|c|c|c|c|c|c|c|c|}
\hline & & $\begin{array}{l}\text { Strongly } \\
\text { Disagree }\end{array}$ & & & Neutral & & & $\begin{array}{c}\text { Strongly } \\
\text { agree }\end{array}$ \\
\hline Q1 & $\begin{array}{l}\text { I will participate in cruise travel } \\
\text { because it is popular among my } \\
\text { friends/family. }\end{array}$ & 1 & 2 & 3 & 4 & 5 & 6 & 7 \\
\hline $\mathrm{Q} 2$ & $\begin{array}{l}\text { I will participate in cruise travel } \\
\text { because my friends/family have } \\
\text { talked a lot about it. }\end{array}$ & 1 & 2 & 3 & 4 & 5 & 6 & 7 \\
\hline Q3 & $\begin{array}{l}\text { I will participate in cruise travel } \\
\text { because it has been recommended } \\
\text { by friends/family. }\end{array}$ & 1 & 2 & 3 & 4 & 5 & 6 & 7 \\
\hline Q4 & $\begin{array}{l}\text { I will participate in cruise travel } \\
\text { because my friends/family } \\
\text { participated. }\end{array}$ & 1 & 2 & 3 & 4 & 5 & 6 & 7 \\
\hline
\end{tabular}




\begin{tabular}{|l|l|l|l|l|l|l|l|l|}
\hline Q5 & $\begin{array}{l}\text { I will participate in cruise travel } \\
\text { because my friends/family think it } \\
\text { is good to participate. }\end{array}$ & 1 & 2 & 3 & 4 & 5 & 6 & 7 \\
\hline
\end{tabular}

Part 3 - Perceived Behavioral Control (PBC) [Ref: Ajzen, 1991; Park et al., 2017;

Chien et al., 2012; Liu, 2019]

\begin{tabular}{|l|l|c|c|c|c|c|c|c|}
\hline \multicolumn{2}{|l}{} & $\begin{array}{c}\text { Strongly } \\
\text { Disagree }\end{array}$ & & Neutral & & $\begin{array}{c}\text { Strongly } \\
\text { agree }\end{array}$ \\
\hline Q1 & $\begin{array}{l}\text { I have enough time to participate } \\
\text { in cruise travel. }\end{array}$ & 1 & 2 & 3 & 4 & 5 & 6 & 7 \\
\hline Q2 & $\begin{array}{l}\text { I have enough money to } \\
\text { participate in cruise travel. }\end{array}$ & 1 & 2 & 3 & 4 & 5 & 6 & 7 \\
\hline Q3 & $\begin{array}{l}\text { I have enough opportunities to } \\
\text { participate in cruise travel. }\end{array}$ & 1 & 2 & 3 & 4 & 5 & 6 & 7 \\
\hline Q4 & $\begin{array}{l}\text { I feel nothing will prevent me } \\
\text { from participating in cruise travel } \\
\text { if I want. }\end{array}$ & 1 & 2 & 3 & 4 & 5 & 6 & 7 \\
\hline Q5 & $\begin{array}{l}\text { If I want, I can easily participate } \\
\text { in cruise travel. }\end{array}$ & 1 & 2 & 3 & 4 & 5 & 6 & 7 \\
\hline
\end{tabular}

Part 4 - Self-esteem \& social recognition [Ref: Hung \& Petrick, 2011; Manfredo et al., 1996; Han \& Hyun, 2019]

\begin{tabular}{|l|l|c|c|c|c|c|c|c|}
\hline \multicolumn{2}{|l|}{} & $\begin{array}{l}\text { Strongly } \\
\text { Disagree }\end{array}$ & & Neutral & & $\begin{array}{c}\text { Strongly } \\
\text { agree }\end{array}$ \\
\hline Q1 & $\begin{array}{l}\text { To do something that impresses } \\
\text { others. }\end{array}$ & 1 & 2 & 3 & 4 & 5 & 6 & 7 \\
\hline Q2 & $\begin{array}{l}\text { To help me feel like a better } \\
\text { person. }\end{array}$ & 1 & 2 & 3 & 4 & 5 & 6 & 7 \\
\hline Q3 & $\begin{array}{l}\text { To increase my feelings of self- } \\
\text { worth. }\end{array}$ & 1 & 2 & 3 & 4 & 5 & 6 & 7 \\
\hline Q4 & $\begin{array}{l}\text { To derive a feeling of } \\
\text { accomplishment. }\end{array}$ & 1 & 2 & 3 & 4 & 5 & 6 & 7 \\
\hline Q5 & $\begin{array}{l}\text { To photograph an exotic place to } \\
\text { show friends. }\end{array}$ & 1 & 2 & 3 & 4 & 5 & 6 & 7 \\
\hline
\end{tabular}

Part 5 - Escape/relaxation [Ref: Hung \& Petrick, 2011; Manfredo et al., 1996; Han \& Hyun, 2019]

\begin{tabular}{|l|l|c|c|c|c|c|c|c|}
\hline \multicolumn{2}{|l|}{} & $\begin{array}{c}\text { Strongly } \\
\text { Disagree }\end{array}$ & & & Neutral & & $\begin{array}{c}\text { Strongly } \\
\text { agree }\end{array}$ \\
\hline Q1 & $\begin{array}{l}\text { So that I can be free to do } \\
\text { whatever I want. }\end{array}$ & 1 & 2 & 3 & 4 & 5 & 6 & 7 \\
\hline Q2 & To give my mind a rest. & 1 & 2 & 3 & 4 & 5 & 6 & 7 \\
\hline Q3 & I cruise to have fun. & 1 & 2 & 3 & 4 & 5 & 6 & 7 \\
\hline
\end{tabular}




\begin{tabular}{|l|l|l|l|l|l|l|l|c|}
\hline Q4 & $\begin{array}{l}\text { To have more privacy than you } \\
\text { have back home. }\end{array}$ & 1 & 2 & 3 & 4 & 5 & 6 & 7 \\
\hline Q5 & $\begin{array}{l}\text { To get away from the usual } \\
\text { demands of life. }\end{array}$ & 1 & 2 & 3 & 4 & 5 & 6 & 7 \\
\hline
\end{tabular}

Part 6 - Learning/discovery \& thrill [Ref: Hung \& Petrick, 2011; Manfredo et al., 1996; Han \& Hyun, 2019]

\begin{tabular}{|l|l|c|c|c|c|c|c|c|}
\hline \multicolumn{2}{|l|}{} & $\begin{array}{c}\text { Strongly } \\
\text { Disagree }\end{array}$ & & & Neutral & & & $\begin{array}{c}\text { Strongly } \\
\text { agree }\end{array}$ \\
\hline Q1 & To gain knowledge. & 1 & 2 & 3 & 4 & 5 & 6 & 7 \\
\hline Q2 & To experience other cultures. & 1 & 2 & 3 & 4 & 5 & 6 & 7 \\
\hline Q3 & To discover something new. & 1 & 2 & 3 & 4 & 5 & 6 & 7 \\
\hline Q4 & To learn more about nature. & 1 & 2 & 3 & 4 & 5 & 6 & 7 \\
\hline
\end{tabular}

Part 7 - Socialization/Bonding [Ref: Hung \& Petrick, 2011; Manfredo et al., 1996;

Han \& Hyun, 2019]

\begin{tabular}{|l|l|c|c|c|c|c|c|c|}
\hline \multicolumn{2}{|l|}{} & $\begin{array}{l}\text { Strongly } \\
\text { Disagree }\end{array}$ & & Neutral & & $\begin{array}{c}\text { Strongl } \\
\text { y agree }\end{array}$ \\
\hline Q1 & $\begin{array}{l}\text { Because my friends/family want } \\
\text { to cruise. }\end{array}$ & 1 & 2 & 3 & 4 & 5 & 6 & 7 \\
\hline Q2 & To interact with friends/family. & 1 & 2 & 3 & 4 & 5 & 6 & 7 \\
\hline Q3 & $\begin{array}{l}\text { Cruising provides me a chance to } \\
\text { meet new people. }\end{array}$ & 1 & 2 & 3 & 4 & 5 & 6 & 7 \\
\hline Q4 & $\begin{array}{l}\text { I cruise because I like to meet } \\
\text { different people on a cruise ship. }\end{array}$ & 1 & 2 & 3 & 4 & 5 & 6 & 7 \\
\hline Q5 & $\begin{array}{l}\text { To be with other who enjoy the } \\
\text { same things you do. }\end{array}$ & 1 & 2 & 3 & 4 & 5 & 6 & 7 \\
\hline
\end{tabular}

Part 8 - Enjoy nature [Ref: Manfredo et al., 1996]

\begin{tabular}{|l|l|c|c|c|c|c|c|c|}
\hline \multicolumn{2}{|l}{} & $\begin{array}{c}\text { Strongly } \\
\text { Disagree }\end{array}$ & & Neutral & & $\begin{array}{c}\text { Strongly } \\
\text { agree }\end{array}$ \\
\hline Q1 & To view the scenic beauty. & 1 & 2 & 3 & 4 & 5 & 6 & 7 \\
\hline Q2 & $\begin{array}{l}\text { To be close to nature (e.g. } \\
\text { Ocean). }\end{array}$ & 1 & 2 & 3 & 4 & 5 & 6 & 7 \\
\hline Q3 & $\begin{array}{l}\text { To enjoy the smells and sounds } \\
\text { of nature. }\end{array}$ & 1 & 2 & 3 & 4 & 5 & 6 & 7 \\
\hline Q4 & To be where things are natural. & 1 & 2 & 3 & 4 & 5 & 6 & 7 \\
\hline
\end{tabular}

Part 9 - Creativity [Ref: Manfredo et al., 1996]

\begin{tabular}{|l|l|c|c|c|c|c|c|c|}
\hline \multicolumn{2}{|l|}{} & $\begin{array}{c}\text { Strongly } \\
\text { Disagree }\end{array}$ & & Neutral & & $\begin{array}{c}\text { Strongly } \\
\text { agree }\end{array}$ \\
\hline Q1 & To be creative. & 1 & 2 & 3 & 4 & 5 & 6 & 7 \\
\hline Q2 & $\begin{array}{l}\text { To do something creative such } \\
\text { as diving, game changers, } \\
\text { marquee shows. }\end{array}$ & 1 & 2 & 3 & 4 & 5 & 6 & 7 \\
\hline
\end{tabular}




\begin{tabular}{|l|l|l|l|l|l|l|l|l|}
\hline Q3 & $\begin{array}{l}\text { To gain a new perspective on } \\
\text { life. }\end{array}$ & 1 & 2 & 3 & 4 & 5 & 6 & 7 \\
\hline
\end{tabular}

Part 10 - Travel Satisfaction (TS) [Ref: Yoon \& Uysal, 2005; Han \& Hyun, 2018]

\begin{tabular}{|l|l|c|c|c|c|c|c|c|}
\hline \multicolumn{2}{|c|}{} & $\begin{array}{c}\text { Strongly } \\
\text { Disagree }\end{array}$ & & Neutral & & $\begin{array}{c}\text { Strongly } \\
\text { agree }\end{array}$ \\
\hline Q1 & $\begin{array}{l}\text { Overall, I am satisfied with my } \\
\text { experience with cruise traveling. }\end{array}$ & 1 & 2 & 3 & 4 & 5 & 6 & 7 \\
\hline Q2 & $\begin{array}{l}\text { Overall, cruise traveling worth } \\
\text { my time and effort. }\end{array}$ & 1 & 2 & 3 & 4 & 5 & 6 & 7 \\
\hline Q3 & $\begin{array}{l}\text { Overall, cruise traveling is much } \\
\text { better than what I expected. }\end{array}$ & 1 & 2 & 3 & 4 & 5 & 6 & 7 \\
\hline Q4 & $\begin{array}{l}\text { Overall, cruise traveling as a } \\
\text { vacation option is much better } \\
\text { than similar options (flight, train, } \\
\text { etc.). }\end{array}$ & 1 & 2 & 3 & 4 & 5 & 6 & 7 \\
\hline
\end{tabular}

Part 11 - Behavioral Intention (INT) [Ref: Park et al., 2017; Fan \& Hsu, 2014; Chien et al., 2012]

\begin{tabular}{|l|l|c|c|c|c|c|c|c|}
\hline \multicolumn{2}{|l}{} & $\begin{array}{c}\text { Strongly } \\
\text { Disagree }\end{array}$ & & Neutral & & $\begin{array}{c}\text { Strongly } \\
\text { agree }\end{array}$ \\
\hline Q1 & $\begin{array}{l}\text { I'll encourage friends/family to } \\
\text { participate in cruise travel. }\end{array}$ & 1 & 2 & 3 & 4 & 5 & 6 & 7 \\
\hline Q2 & $\begin{array}{l}\text { I want to participate in cruise } \\
\text { travel within 12 months. }\end{array}$ & 1 & 2 & 3 & 4 & 5 & 6 & 7 \\
\hline Q3 & $\begin{array}{l}\text { I intend to cruise on special day } \\
\text { in the future (e.g. birthday, } \\
\text { anniversary, etc.). }\end{array}$ & 1 & 2 & 3 & 4 & 5 & 6 & 7 \\
\hline Q4 & $\begin{array}{l}\text { Cruise traveling is my first } \\
\text { choice for traveling in the future. }\end{array}$ & 1 & 2 & 3 & 4 & 5 & 6 & 7 \\
\hline Q5 & $\begin{array}{l}\text { I will save time and money } \\
\text { within 12 months for } \\
\text { participating in cruise travel. }\end{array}$ & 1 & 2 & 3 & 4 & 5 & 6 & 7 \\
\hline
\end{tabular}

Part 12 - Cruise Preference Profile (CPP) [Ref: Fan \& Hsu, 2014]

\section{Q1: What is(are) your most preferred cruise destination(s)?}

\section{Southeast Asia}

2. Europe

3. Korea

4. Middle East 
5. Japan

6. North America

7. None

8. Others ()

Q2: How far in advance would you begin planning your cruise travel?

1. Less than a month

2. 1-2 months

3. 3-4 months

4. 5-6 months

5. More than 6 months

Q3: What is your most preferred cruise booking channel?

1. Online travel agencies

2. Traditional travel agencies

3. Cruise companies

4. Others ()

Q4: What is your most preferred cruise duration?

1. 1-3 days

2. 4-6 days

3. 7-9 days

4. 10-15 days

5. More than 15 days

$\underline{\text { Part } 13 \text { - Personal Information (PI) }}$

Q1: Have you travelled with cruise lines? 
1. Yes (How many times ())

2. No

\section{Q2: GENDER}

1. Male

2. Female

\section{Q3: YOU ARE}

1. Single

2. Married

3. With Partner

Q4: AGE

1. $21-24$

2. $25-34$

3. $35-44$

4. $45-54$

$5.55-64$

6. 65 plus

Q5: TOTAL HOUSEHOLD ANNUAL INCOME

1. RMB 50,000 or less

2. RMB 50,000 - RMB 99,999

3. RMB 100,000 - RMB 149,999

4. $\mathrm{RMB} 150,000$ - RMB 199,999

5. RMB 200,000 - RMB 249,999

6. RMB 250,000 - RMB 299,999 
7. RMB 300,000 - RMB 349,999

8. RMB 350,000 or more

\section{Q6: Where do you live?}

1. North China (Beijing, Tianjin, Hebei, Shanxi, Inner Mongolia)

2. Northeast (Liaoning, Jilin, Heilongjiang)

3. East China (Shanghai, Jiangsu, Zhejiang, Anhui, Fujian, Jiangxi, Shandong)

4. Central and South (Henan, Hubei, Hunan, Guangdong, Guangxi, Hainan, HK, Macau)

5. Southwest (Chongqing, Sichuan, Guizhou, Yunnan, Tibetans)

6. Northwest (Shanxi, Gansu, Qinghai, Ningxia, Xinjiang)

\section{Q7: EDUCATION}

1. High School

2. Associate degree

3. Bachelor's Degree

4. Master's Degree

5. Doctoral Degree

6. Other Education/Trade

Thank you very much for your time and effort in completing this questionnaire. 